\title{
Hydrologic Analysis of Data for the Lost Lake Aquifer Zone of the Steed Pond Aquifer at Recovery Well RWM-16
}

by

D. G. Wells

Westinghouse Savannah River Company

Savannah River Site

Aiken, South Carolina 29808

J. W. Cook

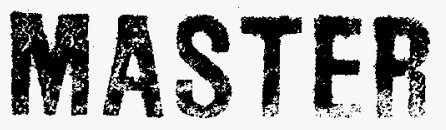

-STRIBUTION OF THIS DOCUMENT IS UNLIMITES

DOE Contract No. DE-AC09-89SR18035

This paper was prepared in connection with work done under the above contract number with the $U$. $S$.

Department of Energy. By acceptance of this paper, the publisher and/or recipient acknowledges the U. S. Government's right to retain a nonexclusive, royalty-free license in and to any copyright covering this paper, along with the right to reproduce and to authorize others to reproduce all or part of the copyrighted paper. 
WSRC-TR-92-529

\section{Hydrologic Analysis of Data for the Lost Lake Aquifer Zone of the Steed Pond Aquifer at Recovery Well RWM-16 ${ }^{(\mathrm{U})}$}

R. A. Hiergesell

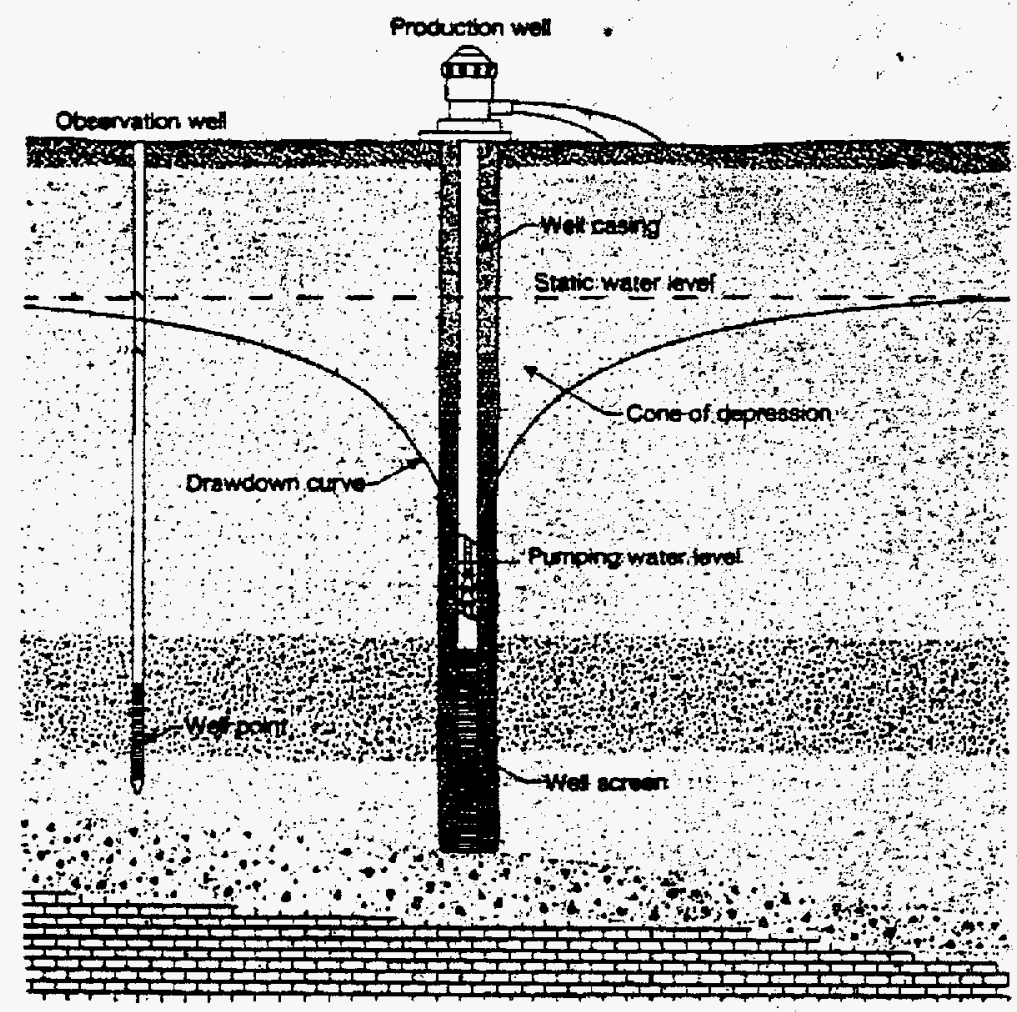

Westinghouse Savannah River Company

Savannah River Site

Aiken, SC 29808

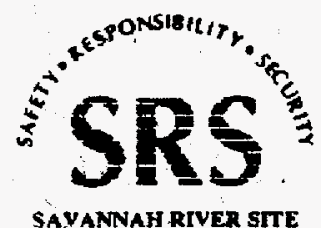

Prepared for the U. S. Department of Energy under Contract No. DE-AC09-89SR 18035 


\section{DISCLAIMER}

This report was prepared as an account of work sponsored by an agency of the United States Government. Neither the United States Government nor any agency thereof, nor any of their employees, makes any warranty, express or implied, or assumes any legal liability or responsibility for the accuracy, completeness, or usefulness of any information, apparatus, product, or process disclosed, or represents that its use would not infringe privately owned rights. Reference herein to any specific commercial product, process, or service by trade name, trademark, manufacturer, or otherwise does not necessarily constitute or imply its endorsement, recommendation, or favoring by the United States Government or any agency thereof. The views and opinions of authors expressed herein do not necessarily state or reflect those of the United States Govemment or any agency thereof.

This report has been reproduced directly from the best available copy.

Available to DOE and DOE contractors from the Office of Scientific and Technical Information, P.O. Box 62, Oak Ridge, TN 37831; prices available from (615) 576-8401.

Available to the public from the National Technical Information Service, U.S. Department of Commerce, 5285 Port Royal Road, Springfield, VA 22161.

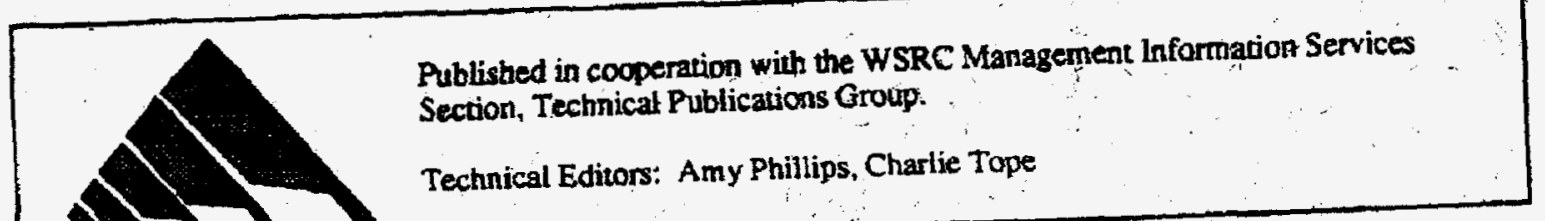




\section{DISCLAMMER}

Portions of this document may be illegible in electronic image products. Images are produced from the best available original document. 
WSRC-TR-92-529

Publication Date: April 1993

\section{Hydrologic Analysis of Data for the Lost Lake Aquifer Zone of the Steed Pond Aquifer at Recovery Well RWM-16 (U)}

\section{R. A. Hiergesell}

Westinghouse Savannah River Company

Savannah River Site

Aiken, SC 29808

Prepared for the U. S. Department of Energy under Contract No. DE-AC09-89SR18035 



\section{TABLE OF CONTENTS}

INIRODUCTION AND PURPOSE $\ldots \ldots \ldots \ldots \ldots \ldots \ldots, 1$

PROCEDURES $\ldots \ldots \ldots \ldots \ldots \ldots \ldots \ldots \ldots \ldots \ldots \ldots \ldots$

ANAL YTICAL METHODS $\ldots \ldots \ldots \ldots \ldots \ldots \ldots \ldots \ldots, 2$

Barometric Efficiency ................. 2

Aquifer Parameters $\ldots \ldots \ldots \ldots \ldots \ldots \ldots \ldots \ldots$

RESULTS AND DISCUSSION $\ldots \ldots \ldots \ldots \ldots \ldots \ldots \ldots, 5$

REFERENCES $\ldots \ldots \ldots \ldots \ldots \ldots \ldots \ldots \ldots \ldots \ldots \ldots \ldots, 8$

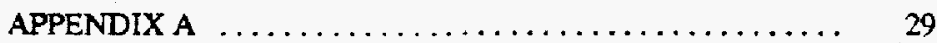




\section{LIST OF FIGURES}

Figure 1. Lacation of RWM-16 in 700 Area ......... 11

Figure 2. Location of Wells in Vicinity of RWM-16 ..... 12

Figure 3. Stratigraphy, Geophysical Logs, and Well Screen Elevations

Figure 4. Correlation of Atmospheric Pressure With MSB-40B Water Levels

Figure 5. Theis Drawdown Analysis for RWM-16PA

Figure 6. Hantush-Jacob (1955) Analysis for RWM-16PA .. 16

Figure 7. Hantush (1960) Analysis for RWM-16PA ..... 17

Figure 8. Theis Recovery Analysis for RWM-16PA ...... 18

Figure 9. Theis Drawdown Analysis for RWM-16PB ..... 19

Figure 10. Hantush-Jacob (1955) Analysis for RWM-16PB . . . 20

Figure 11. Hantush (1960) Analysis for RWM-16PB ..... 21

Figure 12. Theis Recovery Analysis for RWM-16PB ..... 22

Figure 13. Theis Drawdown Analysis for MSB-40B $\ldots \ldots \ldots 23$

Figure 14. Hantush-Jacob (1955) Analysis for MSB-40B ... 24

Figure 15. Hantush (1960) Analysis for MSB-40B . . . . . . 25

Figure 16. Theis Recovery Analysis for MSB-40B . . . . . . 26

Figure 17. Drawdown vs. Log Distance from RWM-16 ..... 27 


\section{LIST OF TABLES}

Table 1. Well Information for Pump Test at RWM-16 ... 2

Table 2. Test Results $\ldots \ldots \ldots \ldots \ldots \ldots \ldots \ldots \ldots \ldots$

Table 3. Hydraulic Conductivily Values $\ldots \ldots \ldots \ldots \ldots$ 


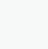

BLANK 


\section{Hydrologic Analysis of Data for the Lost Lake Aquifer Zone of the Steed Pond Aquifer at Recovery Well RWM-16}

\section{INTRODUCTION AND PURPOSE}

This report presents the results of an analysis of data obtained from a large-scale, multiple-well aquifer test of the sandy unit referred to as the Lost Lake Aquifer Zone of the Steed Pond Aquifer in an area just south of the $A$ and $M$ Areas. Pumping was conducted at recovery well RWM-16, which is located near the MSB -40 well cluster, approx imately 4000 feet south of the M-Area Basin. RWM-16 is located in the lower left portion of Figure 1, which also illustrates the general relationship of the testing site to the $A$ and $M$ Areas and other monitor wells.

The data generated from testing RWM-16 was used to calculate estimates of transmissivity and storage for the aquifer system within which RWM-16 is screened. These parameters are related to hydraulic conductivity and storativity of the aquifer system by the vertical thickness of the unit The leakage coefficient for the overlying confining unit is also estimated.

This information is needed to refine conceptual understanding of the groundwater flow system beneath the $A$ and $M$ Areas. The refined conceptual model will more adequately describe the pattern of groundwater flow, and will contribute to updating the "Zone of Capture" model that has been used in the initial phases of designing a groundwaler romediation system in the $A$ and M Areas.

\section{PROCEDURES}

Only a bricf description of field testing conditions and procedures is presented in this report. A more detailed description of the layout of wells and the conduct of the test is presented in ESH-EMS-92-0165, Report of Data Generated During the Aquifer Test at RWM-16 (Hiergesell, 1992).

The layout of wells in the immediate vicinity of RWM-16 is illustrated in Figure 2. Well screen elevations for the principal wells monitored during the aquifer test are plotted in relation to the hydrostratigraphic units in the vicinity of RWM-16 in Figure 3. Hydrostratigraphic contacts are from a report entitled $H$ ydrogeologic Setting of A/M Area: Framework for Groundwater Transport (WSRC-TR-92-355, Lewis, S. E., and Aadland, R. K., 1992). ${ }^{2}$ Geophysical logs in this figure are those obtained at the time the MSB -40 well cluster was installed.

Testing was achieved by withdrawing water from the pumping well, RWM-16, and monitoring for changes in water levels in nearby piezometers. These wells were monitored during both the pumping and the recovery periods of the test. Pumping proceeded at a relatively constant rate of about 39 gallons per minute during the 72 -hour pumping period. Following this, the pump was tumed off and the water level recovery was monitored for another 72 hours. Antecedent water levels were monitored in certain wells for approximately 3.5 days before pumping was started.

Water level changes were monitored using a pressure transducer/data logging system as well as with electrical measuring lapes. Transducers were dedicated in RWM-16, MSB-40B, and RWM-16PA and RWM-16PB. Electrical tapes were used to obtain periodic measurements in these same wells and to monitor more distant wells. The SRS coordinates for each well, the 
calculated distances of each from RWM-16, and other pertinent well information are presented in Table 1.

Pumping rates were monitored by periodically filling a barrel of known volume and timing the duration to fill the barrel. An online totaling flow meter was also used to estimate pumping rate.

Table 1. Well Information for Pump Test at RWM-16

Well

\begin{tabular}{|c|c|c|c|c|c|c|}
\hline Coord. $N$ & $\begin{array}{l}\text { SRP } \\
\text { Coord. E }\end{array}$ & $\begin{array}{l}\text { Dist to } \\
\text { RWM-16 }\end{array}$ & $\begin{array}{l}\text { Elev. } \\
\text { top of } \\
\text { Casing }\end{array}$ & $\begin{array}{l}\text { Elev. } \\
\text { top of } \\
\text { Stand Pipe }\end{array}$ & $\begin{array}{l}\text { Water } \\
\text { Level } \\
\text { Elev. } \\
(3 / 19 / 91)\end{array}$ & $\begin{array}{l}\text { Elev. } \\
\text { top of } \\
\text { Screen }\end{array}$ \\
\hline
\end{tabular}

(ft)

(ft)

(ft)

(ft)

(fi)

(ft)

(ft)

(fi)

RWM-16

97647.2

48244.8

48364.9

0

322.62

181.9

330.35

RWM-16PB

97783.9

48212.5

40.8

319.91

MSB-40B

97685.0

48281.6

52.7

\section{6}

202.72

201.82

188.4

188.9

35.8

-

321.70

- 202.38

$321.9 \quad 202.82$

189.3

155.7

40.1

40.1

5.6

\section{ANALYTICAL METHODS}

\section{Barometric Efficiency}

Changes in atmospheric or barometric pressure were obtained from measurements made by the U.S. Weather Service at Bush Field every 15 minules during the time of field operations for the pump test at RWM-16. A plot of atmospheric pressure measurements, in feet of water, is presented in Figure 4 with concurrent water levels from MSB-40B superimposed. A strong inverse relationship is apparent between these swo curves, indicating that atmospheric pressure changes are influencing water levels observed in monitor wells. Corrections were made to the raw measurements by using the following equation:

$\Delta w .1 .=(B E)^{*}(\Delta B p) / 100$. (Ferris, et al., 1962)

In this equation:

$\Delta w .1 .=$ the change in water level relative to the reference water level,

$B E=$ the barometric efficiency of the well,

$\Delta B p=$ the change in barometric pressure relative to the reference pressure,

where, $B E=(\Delta \text { w.l. })^{*}(100) /(\Delta B p)$

The reference atmospheric pressure was the pressure at the time pumping started, while the reference water ievel was the electric tape measurement that was taken just before the pumping was initiated. Water level measurements taken prior to and after this instant, $t=0$, were corrected with respect to that reference atmospheric pressure. Determination of barometric efficiency (BE) was made for each well that was insurumented with a pressure transducer. BE determinations and water level corrections were made using a spreadsheet program with dynamic update capability for its graphs. The correct BE was selected by repeatedly using 
values ranging from $50 \%$ to $80 \%$ and noting the configuration of the water levels in the antecedent portion of the hydrograph. Optimum BE values were identified by observing which value produced the straightest line in the antecedent periods and also the smoothest curves in the drawdown and recovery portions of the aquifer test. These values were determined to be $60 \%$, 55\%, and 60\% for MSB-40B, RWM-16PA, and RWM-16PB, respectively.

Aquifer Parameters

The principal parameters which describe an aquifer's capacity to store and transmit water are transmissivity ( $T$ ) and storativity or storage coefficient $(S)$. Leakance $(\mathrm{r} / \mathrm{B})$ is another parameser that describes the capacity of a confining unit to transmit water between overlying and underlying aquifer units. Values for each of these parameters were estimated at each of the monitor wells having transducers dedicated in them, RWM-16PA, RWM-16PB, and MSB-40B.

Determinations of these parameters were made using the drawdown data and three different methodologies, each having application in slightly different hydrogeologic settings. The (Theis, 1935) method describes the approach to estimating $T$ and $S$ from drawdown data in a confined setting. The paper also describes a method to estimate $T$ from recovery data. In the Theis approach, the theoretical solurion assumes that no leakage from adjacent formations be induced by drawdown in the pumped formation. Two other methods, (Hantush-Jacob, 1955) and (Hantush, 1960) ${ }^{\circ}$, describe theoretical approaches to determining $T, S, r / B$, and $\beta$ in seuings where leakage from adjacent formations is induced into the pumped formation by drawdown in that formation. The difference between these two is that the latter approach accounts for water released from storage within the confining unit in its solution and also accounts for two confining layers, one above and one below the pumped formation. $\beta$ is defined later in the report.

Basic assumptions common to all of the methods are presented below:

- the aquifer has an infinite areal extent

- the aquifer is homogenous, isotropic, and of uniform thickness

- the aquifer has a horizontal potentiometric surface

- the aquifer is confined

- the pumping rate is steady

- the puraping well is fully penetrating

- flow to the pumping well is horizontal

- water is released instantaneously from storage with decline in hydraulic head

- the diameter of the pumping well is very small so that storage in the well can be neglected

The following additional assumptions apply to the (Hantush-Jacob, 1955) ${ }^{\mathrm{s}}$ and (Hantush, 1960) 6 methods:

- the confining bed has an infinite areal extent, uniform verucal hydraulic conductivity, and uniform thickness

- the confining bed is overlain or underlain by an infinite constant head plane source

- flow in the confining bed is vertical

While these assumptions can never be completely satisfied in application of the theory to field conditions and data, the analysis approach still has practical value. If efforts are made to instrument a site to meet cerain assumptions. and other assumptions are not grossly deviated from, the approach can still provide valid and useful results. Appendix A contains a brief 
description of the references, solution formulas, and assumptions inherent with each approach.

The parameters mentioned above (T, S, and B) are defined as follows:

$\mathrm{T}=\mathrm{Q} / 4 \pi \mathrm{s}^{*} \mathrm{~W}(\mathrm{u})$

where $W(u)$ is the "well function of $u$ " and represents an exponential integral, and

$u=\left(r^{2} S\right) /(4 T t)$ where

$r=$ radial distance between the pumping and observation well, in $m$

$S=$ storage coefficient, dimensionless

$\mathrm{T}=$ transmissivity, in $\mathrm{m}^{2} /$ day

$\mathrm{t}=\mathrm{time}$, in days

$s=$ drawdown in the observation well, in $m$, and

$Q=$ pumping rate, in $\mathrm{m}^{3} /$ day

$S=4 T(t / r) u(t e r m s$ are defined above)

$B=\left(T b^{\prime} / K\right)^{1 / 2}$ where

$\mathrm{T}=$ transmissivity of aquifer

$b^{\prime}=$ thickness of the leaky layer, in $m$, and

$\mathbf{K}^{\prime}=$ vertical hydraulic conductivity of the leaky layer, in $\mathrm{m} /$ day

In accounting for storage in leaky confining layers, one above and one below the pumped aquifer, a dimensionless parameter $\beta$ is described in (Hantush, 1960). ${ }^{6}$ This parameter is defined as follows:

$\beta=\frac{T}{4}\left[\left(\frac{K^{\prime} S^{\prime}}{b^{\prime} T S}\right)^{1 / 2}+\left(\frac{K^{11} S^{i 1}}{b^{11} T S}\right)^{1 / 2}\right]$

where the lettered parameters have all been defined above, and the ' and " notation refer to the overlying and underlying leaky confining layers respectively.

Analysis of drawdown and recovery data using the above methods all utilize the approach of matching the theoretical type curve with a time-drawdown curve of field data. The process is automated in this anialysis by using the PC program AQTESOLV, version 1.0, developed by Geraghty and Miller, Inc.

As mentioned, drawdown and recovery data were initially corrected for barometric pressure fluctuation during the time period of field data collection. Files of drawdown data were then created using a spreadsheet program. These files were then read into AQTESOLV. The program matches the type curves of the analytical solutions against graphs of the drawdown and recovery data. Matching can be done manually, by the user, or with an automatic routine that employs a non-linear least-squares minimization algorithm. The latter is a systematic method that usualiy resul is in as good a fit as.is possible for the theoretical and field curves, and is the method used in this analysis. 
AQTESOLV can use any consistent set of length and ume units to solve for aquifer and leakance parameters. Field measurements were made in feet for drawdown and gallons per minute for pumping rate. Conversions were made to these measurements in a spreadsheet program to obtain equivalent values for pumping rate in cubic feet per minute.

It should be pointed out that the drawdown data utilized in this analysis were those measurements taken using the data logger and downhole pressure transducers. Although periodic drawdown measurements were taken in the same wells using an electric tape, these were not used to calculate aquifer parameters.

Because the field data are plotted on logarithmic graphs within AQTESOLV, each log cycle had different numbers of data points. To prevent the program from biasing the curve match toward those parts of the curve having the most closely spaced data points when the non-linear least-squares minimization algorithm is used, weighting factors were incorporated into the data file for each measurement based upon how many data points occurred within each log cycle. Within AQTESOLV, a weighting factor is required for each measurement that is input to the program. Such a mechanism allows for more realistic curve matches when the "least-squares" algorithm is applied to unevenly spaced data points.

To analyze the recovery of water levels after pumping ceases, a plot of residual drawdown versus the $\log$ of $t t^{1}$ was employed. In this approach, $t$ is the elapsed time since pumping started, and $t^{\prime}$ is the elapsed time following the cessation of pumping. Residual drawdown is the drawdown measured in the well following cessation of pumping, relative to the initial water level. Early time recovery data, when ${ }^{\prime} \mathrm{l}^{\prime}$ is very large, is not a relevant portion of the data curve. For relatively large $t$ and small $r$ rvalves, the analytical relationship is approximated by a straight line. The straight line portion can therefore be utilized to determine T. AQTESOLV allows the user to manually fit a straight line to the data plot The slope of the straight-line portion is used to calculate the $T$ value using the following formula:

$T=0.183^{\bullet} Q /\left(\Delta s^{\prime}\right)$ where

$\mathrm{Q}=$ pumping rate, in $\mathrm{m}^{3} / \mathrm{day}$, and $\Delta \mathrm{s}^{1}=$ residual drawdown occurning over $1 \log$ cycle, in $\mathrm{m}$, and $\mathrm{T}=$ transmissivity, in $\mathrm{m}^{2} /$ day.

\section{RESULTS AND DISCUSSION}

Analysis results were obtained from drawdown measurements taken in RWM-16PA, RWM-16PB, and MSB-40B. Although a pressure transducer was dedicated in recovery well RWM-16 and water level changes were recorded, no analysis was done on that data because of the extreme sensitivity of those water levels to small fluctuations in pumping rate.

Values for transmissivities, storativities, and leakance values calculated in the data analysis are presented in Tables 2 and 3. Plots of the individual time-drawdown graphs for each well analysis are presented in Figures 5 through 16. Results of transmissivity estimates are consistent with the analytical constraints imposed by the assumptions of the theoretical approaches of (Theis, 1935), (Hantush-Jacob, 1955), and (Hantush, 1960) 6 . Transmissivity estimates are slightly larger for the Theis appraaches, both in the drawdown and recovery methodologies, than for the Hantush approaches. If the solution is constrained by the assumption that all of the pumped water criginates strictly within the pumped formation, then a slightly higher capacity to transmit water is required in order to relate the water level drawdown with a particular pumping rate. 


\begin{tabular}{|c|c|c|c|c|}
\hline \multicolumn{2}{|c|}{ Table 2. Test Results } & \multirow{2}{*}{$\begin{array}{c}\text { RWM-16PA } \\
1.02 \mathrm{E}+00 \\
9.47 \mathrm{E}-02 \\
5.80 \mathrm{E}-04\end{array}$} & \multirow{2}{*}{$\begin{array}{c}\text { RWM-16PB } \\
9.67 \mathrm{E}-01 \\
8.89 \mathrm{E}-02 \\
6.30 \mathrm{E}-04\end{array}$} & \multirow{2}{*}{$\begin{array}{c}\text { MSB-40B } \\
9.00 \mathrm{E}-01 \\
8.36 \mathrm{E}-02 \\
4.70 \mathrm{E}-04\end{array}$} \\
\hline $\begin{array}{l}\text { Theis } \\
\text { Drawdown }\end{array}$ & $\begin{array}{l}T\left(\mathrm{ft}^{2 / m i n}\right) \\
T\left(m^{2} / \min \right) \\
S\end{array}$ & & & \\
\hline $\begin{array}{l}\text { Theis } \\
\text { Recovery }\end{array}$ & $\begin{array}{l}T\left(\mathrm{ft}^{2} / \mathrm{min}\right) \\
\mathrm{T}\left(\mathrm{m}^{2} / \mathrm{min}\right)\end{array}$ & $\begin{array}{l}9.75 E-01 \\
9.05 E-02\end{array}$ & $\begin{array}{l}9.89 \mathrm{E}-01 \\
9.19 \mathrm{E}-02\end{array}$ & $\begin{array}{l}9.56 \mathrm{E}-01 \\
8.88 \mathrm{E}-02\end{array}$ \\
\hline $\begin{array}{l}\text { Hantush-Jacob } \\
\text { (no storage) }\end{array}$ & $\begin{array}{l}\mathrm{T}\left(\mathrm{ft}^{2} / \mathrm{min}\right) \\
\mathrm{T}\left(\mathrm{m}^{2} / \mathrm{min}\right) \\
\mathrm{S} \\
\mathrm{r} / \mathrm{B}\end{array}$ & $\begin{array}{l}8.99 \mathrm{E}-01 \\
8.35 \mathrm{E}-02 \\
6.50 \mathrm{E}-04 \\
8.23 \mathrm{E}-02\end{array}$ & $\begin{array}{l}\text { 8.26E-01 } \\
7.67 \mathrm{E}-02 \\
7.30 \mathrm{E}-04 \\
4.60 \mathrm{E}-02\end{array}$ & $\begin{array}{l}7.82 \mathrm{E}-01 \\
7.26 \mathrm{E}-02 \\
5.30 \mathrm{E}-04 \\
4.58 \mathrm{E}-02\end{array}$ \\
\hline $\begin{array}{l}\text { Hantush } \\
\text { (with storage) }\end{array}$ & $\begin{array}{l}\mathrm{T}\left(\mathrm{ft}^{2} / \mathrm{min}\right) \\
\mathrm{T}\left(\mathrm{m}^{2} / \mathrm{min}\right) \\
\mathrm{S} \\
\beta\end{array}$ & $\begin{array}{l}8.22 E-01 \\
7.64 E-02 \\
5.90 E-04 \\
3.27 E-02\end{array}$ & $\begin{array}{l}6.80 E-01 \\
6.31 E-02 \\
6.20 E-04 \\
5.33 E-02\end{array}$ & $\begin{array}{l}6.23 \mathrm{E}-01 \\
5.79 \mathrm{E}-02 \\
4.50 \mathrm{E}-04 \\
6.01 \mathrm{E}-02\end{array}$ \\
\hline \multicolumn{5}{|c|}{ Note: $\mathbf{r} / \mathbf{B}, \boldsymbol{\beta}$, and $S$ are dimensionless } \\
\hline
\end{tabular}

Table 3. Hydraulic Conductivity Values

\begin{tabular}{|c|c|c|c|c|c|c|}
\hline & ft/day & $\mathrm{ft} / \mathrm{min}$ & $\mathrm{f} / \mathrm{sec}$ & $\mathrm{m} / \mathrm{sec}$ & $\mathrm{cm} / \mathrm{sec}$ & $\mathrm{m} /$ day \\
\hline $\begin{array}{l}\text { Theis Drawdo } \\
\text { RWM-16PA } \\
\text { RWM-16PB } \\
\text { MSB-40B }\end{array}$ & $\begin{array}{l}3.65 E+01 \\
3.47 E+01 \\
3.23 E+01\end{array}$ & $\begin{array}{l}2.54 \mathrm{E}-02 \\
2.41 \mathrm{E}-02 \\
2.25 \mathrm{E}-02\end{array}$ & $\begin{array}{l}4.24 \mathrm{E}-04 \\
4.02 \mathrm{E}-04 \\
3.74 \mathrm{E}-04\end{array}$ & $\begin{array}{l}1.29 E-04 \\
1.22 E-04 \\
1.14 E-04\end{array}$ & $\begin{array}{l}1.29 \mathrm{E}-06 \\
1.22 \mathrm{E}-06 \\
1.02 \mathrm{E}-06\end{array}$ & $\begin{array}{l}1.12 E+01 \\
1.06 E+01 \\
9.85 E+00\end{array}$ \\
\hline $\begin{array}{l}\text { Hantush-Jacob } \\
\text { RWM-16PA } \\
\text { RWM-16PB } \\
\text { MSB-40B }\end{array}$ & $\begin{array}{l}3.23 E+01 \\
2.96 E+01 \\
2.81 E+01\end{array}$ & $\begin{array}{l}2.24 \mathrm{E}-02 \\
2.06 \mathrm{E}-02 \\
1.95 \mathrm{E}-02\end{array}$ & $\begin{array}{l}3.74 \mathrm{E}-04 \\
3.43 \mathrm{E}-04 \\
3.25 \mathrm{E}-04\end{array}$ & $\begin{array}{l}1.14 \mathrm{E}-04 \\
1.05 \mathrm{E}-04 \\
9.91 \mathrm{E}-05\end{array}$ & $\begin{array}{l}1.14 \mathrm{E}-06 \\
1.05 \mathrm{E}-06 \\
9.91 \mathrm{E}-07\end{array}$ & $\begin{array}{l}9.84 E+00 \\
9.04 E+00 \\
8.56 E+00\end{array}$ \\
\hline $\begin{array}{l}\text { Hantush } \\
\text { RWM-16PA } \\
\text { RWM-16PB } \\
\text { MSB-40B }\end{array}$ & $\begin{array}{l}2.95 E+01 \\
2.44 E+01 \\
2.24 E+01\end{array}$ & $\begin{array}{l}2.05 E-02 \\
1.70 E-02 \\
1.55 E-02\end{array}$ & $\begin{array}{l}3.42 \mathrm{E}-04 \\
2.83 \mathrm{E}-04 \\
2.59 \mathrm{E}-04\end{array}$ & $\begin{array}{l}1.04 E-04 \\
8.61 E-05 \\
7.89 E-05\end{array}$ & $\begin{array}{l}1.04 \mathrm{E}-06 \\
8.61 \mathrm{E}-07 \\
7.89 \mathrm{E}-07\end{array}$ & $\begin{array}{l}9.00 E+00 \\
7.44 E+00 \\
6.82 E+00\end{array}$ \\
\hline $\begin{array}{l}\text { Theis Rocoven } \\
\text { RWM-16PA } \\
\text { RWM-16PB } \\
\text { MSB-40B }\end{array}$ & $\begin{array}{l}3.50 \mathrm{E}+01 \\
3.55 \mathrm{E}+01 \\
3.43 \mathrm{E}+01\end{array}$ & $\begin{array}{l}2.43 E-02 \\
2.47 E-02 \\
2.38 E-02\end{array}$ & $\begin{array}{l}4.05 \mathrm{E}-04 \\
4.11 \mathrm{E}-04 \\
3.97 \mathrm{E}-04\end{array}$ & $\begin{array}{l}1.23 \mathrm{E}-04 \\
1.25 \mathrm{E}-04 \\
1.2 \mathrm{FE}-04\end{array}$ & $\begin{array}{l}1.23 \mathrm{E}-06 \\
1.25 \mathrm{E}-06 \\
1.21 \mathrm{E}-06\end{array}$ & $\begin{array}{l}1.07 \mathrm{E}+01 \\
1.08 \mathrm{E}+01 \\
1.05 \mathrm{E}+01\end{array}$ \\
\hline ote: Aquifer & d to be 40 & & & & & \\
\hline
\end{tabular}

In real-worid conditions, low permeability units that act to confine higher permeability units are scill able to transmit some water. Likewise these units are capable of storing water within their pore space and also through the compressibility of water when it is subjected to pressure. For this reason it is usually thought that the (Hantush, 1960) ${ }^{6}$ analytical models, which account for leakage from adjacent layers and confining unit storage, are more valid for analysis of data generated in most field settings. In the vicinity of $R$ WM-16, the overlying confining unit is relatively thin, being in the order of 5 to 6 feet. The water table is only several feet higher than the top of this unit. Consequently, it appears that this unit could not contribute a significant quantity of water from storage. Although this is not definitive, it suggests that the (Hantush-Jacob, 1955) method may be the most appropriate for this seuting. 
Transmissivities ranged from $9.47 \mathrm{E}-02$ to $5.79 \mathrm{E}-02 \mathrm{~m}^{2} / \mathrm{min}$. This corresponds to a range of $1.148 \times 10^{-6}$ to $7.036 \times 10^{-7} \mathrm{~cm} / \mathrm{sec}$ hydraulic conduclivity. Hydraulic conductivities are determined by dividing the transmissivity estimates by the pumped formation thickness. For these calculations a value of $40.1 \mathrm{ft}$ was used as formation thickness. This value was selected because it represents the screen lengths of the RWM- 16 wells and corresponds very closely to actual formation thickness. The Theis method gave the high estimate at RWM-16PA while the Hantush method, accounting for confining unit storage, gave the lowest estimate at MSB-40B.

Storativities ranged from 7.3E-04 to 4.5E-04 and are dimensionless quantities. The highest estimate was with the Hantush, no storage method, at RWM-16PA; while the low estimate was obtained from the Hantush, with storage method, at MSB-40B.

Leakance values generated from the Hantush (1955) ${ }^{6}$ method, $\mathrm{r} / \mathrm{B}$, ranged from $8.2 \mathrm{E}-02$ to $4.6 \mathrm{E}-02$. Values generated from the Hantush-Jacob $(1960)^{7}$ method, $\beta$, ranged from $3.3 \mathrm{E}-02$ to $6.0 \mathrm{E}-02$

Following the construction of RWM-16 and the associated piezometers, it was believed that pumping capacity of RWM- 16 would be in the 50 to 75 gallon per minute range. Despite the fact that the well was developed extensively and the dispersing agent sodium hexametaphosphate was used, the maximum sustainable pumping capacity has been in the 35 to 40 gallon per minute range.

Initially it was thought that the sand formation, within which the well is constructed, was simply less transmissive than in other pars of the 700 Areas. Although this may be the case to some degree, it appears that formation transmissivity is not low enough to explain the nearly 40 feet of instantaneous drawdown that is observed within RWM-16 after pumping is stanted.

Two approaches were utilized to assess the causes of the large pumping well drawdown. A distance-drawdown graph was constructed to use water level drawdowns at remote observation wells to project expected drawdowns at the pumping well. When distance is plotted on a logarithmic scale, a straight line connecting the water levels can be extrapolated to the pumping well. This graph is presented in Figure 17. On Figure 17 straight lines connect drawdowns observed at RWM-16PA, $P$ and $B$, and MSB $-40 B$ for four different times $t=100$, $t=500, t=1000$, and $t=4000$ minutes, after pumping is started. Drawdown projections at the pumping well never exceed 8 feet, even at $t=4000$ minutes. Since drawdown at $R W M-16$ was approximately 40 feet at $t=4000$ minutes, drawdown is approximately 5 times greater than expected.

The second approach is to use a value of transmissivity estimated from time-drawdown data generated at one of the remote observation wells (RWM-16PA, RWM-16PB, or MSB-40B) and use this value to calculate expected drawdown close to the perimeter of the gravel pack at RWM-16 (approximately at $r=0.75$ feet). In this approach, the Cooper-Jacob (1946) ${ }^{\mathrm{l}}$ method was utilized. This method is a modified use of the criginalTheis $(1935)^{3}$ formula for situations when the value of $u$ falls below approximately 0.05 . In general, a meets this criteria when $r$ (radial distance) is small or $t$ (time) is large. The applicable equation to calculate drawdown (s) is as follows:

$S=\left(0.183 * Q / T * \log \left[(2.25 * T * t) /\left(r^{2} * S\right)\right]\right.$

using $T=133.8 \mathrm{~m}^{2} /$ day

$Q=212.6 \mathrm{~m}^{\mathrm{s}} /$ day 
$S=0.0005$

$r=0.254 \mathrm{~m}(0.8 \mathrm{ft}$.

$t=2.778$ days $(4000 \mathrm{~min})$

$s=2.16$ meters $(7.1 \mathrm{ft})$

Lines of evidence from both appraaches are consistent in indicating that the amount of head loss within RWM-16 during pumping is much greater than what would be expected if aquifer transmissive characteristics were the controlling factor in determining the pumping level within the well. Two possible explanations for the excessive head loss within the well are most likely. First, inappropriate sizing of the gravel filter pack or screen slot size could be creating excessive head loss. Secondly, the drilling operation during the well installation process utilized a bentonite-based (clay) drilling fluid. The drilling fluid may have infiltrated the sand formation surrounding the well bore and "damaged" the natural formation by decreasing the hydraulic conductivity in a cylindrical zone surrounding the well bore. Normal construction practices employ a well development procedure of pumping and surging to loosen fine textured material from the formation adjacent to the well and remove it by pumping. In the case of RWM-16 such a practice was employed, and a surfactant, sodium bexametaphosphate, was introduced to help remove clay from the formation. Even so, pumping capacity of the well has not exceeded 40 gallons per minute.

If this well is expected to be a key well in the network of remediation wells in the $700 \mathrm{Area}$, it may be advisable to redevelop this well, again using a surfactant, to see if well capacity can be improved. It would also be advisable to reconsider the use of bentonite drilling fluids for wells that are expected to be utilized for production. Altemative drilling fluids using a natural organic polymer are commonly used in the well drilling industry and should be experimented with for production well installation at SRS. These compounds are biodegradable in relatively short periods of time (days) and can be purged by well pumping. Any excessive biological activity can easily be eliminated through disinfecting with a chlorine solution, and the disinfectant parged as well. This approach is commonly used for instal lation of municipal and industrial wells within the industry.

\section{REFERENCES}

1. Hiergesell, R.A., 1992, "Report of Data Generated During the Aquifer Test at RWM-16", ESH-EMS-0165, Westinghouse Savannah River Co., Aiken, SC 29808.

2. Lewis, S. E., and Aadland, R. K., 1992, "Hydrogeologic Setting of A/M Area: Framework for Groundwater Transport", WSRC-TR-92-355, Westinghouse Savannah River Co., Aiken, SC 29808.

3. Ferris, J.G., Knowles, D. B., Brown, R. H., and Stallman, R.W., 1962, "Theory of Aquifer Tests", U.S.G.S. Water Supply Paper 1536-E.

4. Theis, C. V., 1935, "The Relation Between the Lowering of the Piezometric Surface and the Rate Duration of Discharge of a Well Using Ground-Water Storage". American Geophysical Union Transcript, Vol 16, pp 519-524. 
5. Hantush, M.S., and Jacob, CE., 1955. "Non-Steady Radial Flow in an Infinite Leaky Aquife". Transactions of the American Geophysical Union, Vol 36, pp 95-100.

6. Hantush, M.S., 1960, “Modification of the Theory of Leaky Aquifers". Journal of Geophysical Research, Vol 65, No. 11, pp 3713-3725.

7. Cooper, H. J., Jr., and Jacob, C. E., 1946, "A Generalized Graphical Method for Evalualing Formation Constants and Summarizing Well Field History". Transactions of the American Geophysical Union, Vol 27, pp 526-534. 


\section{BLANK}




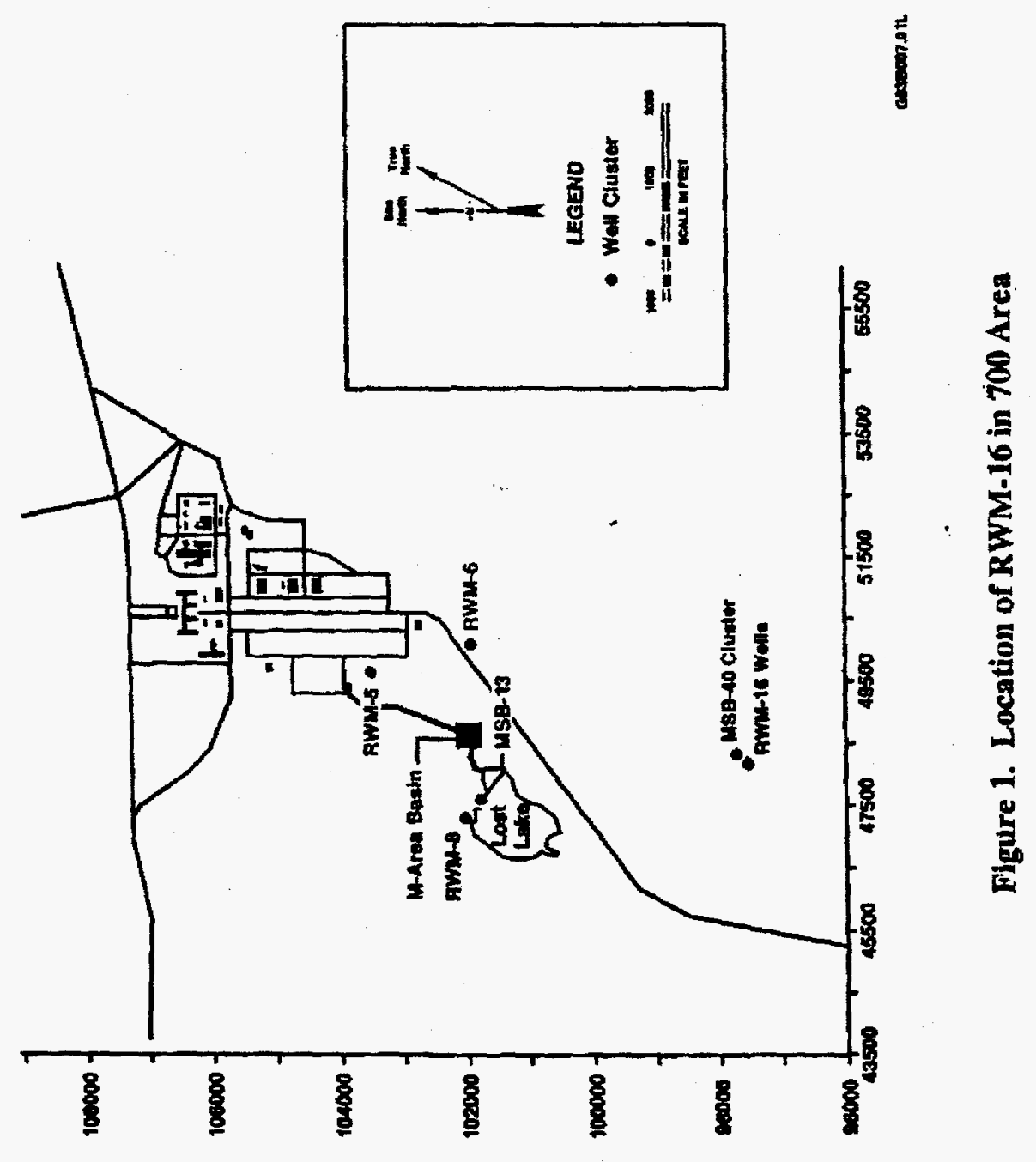




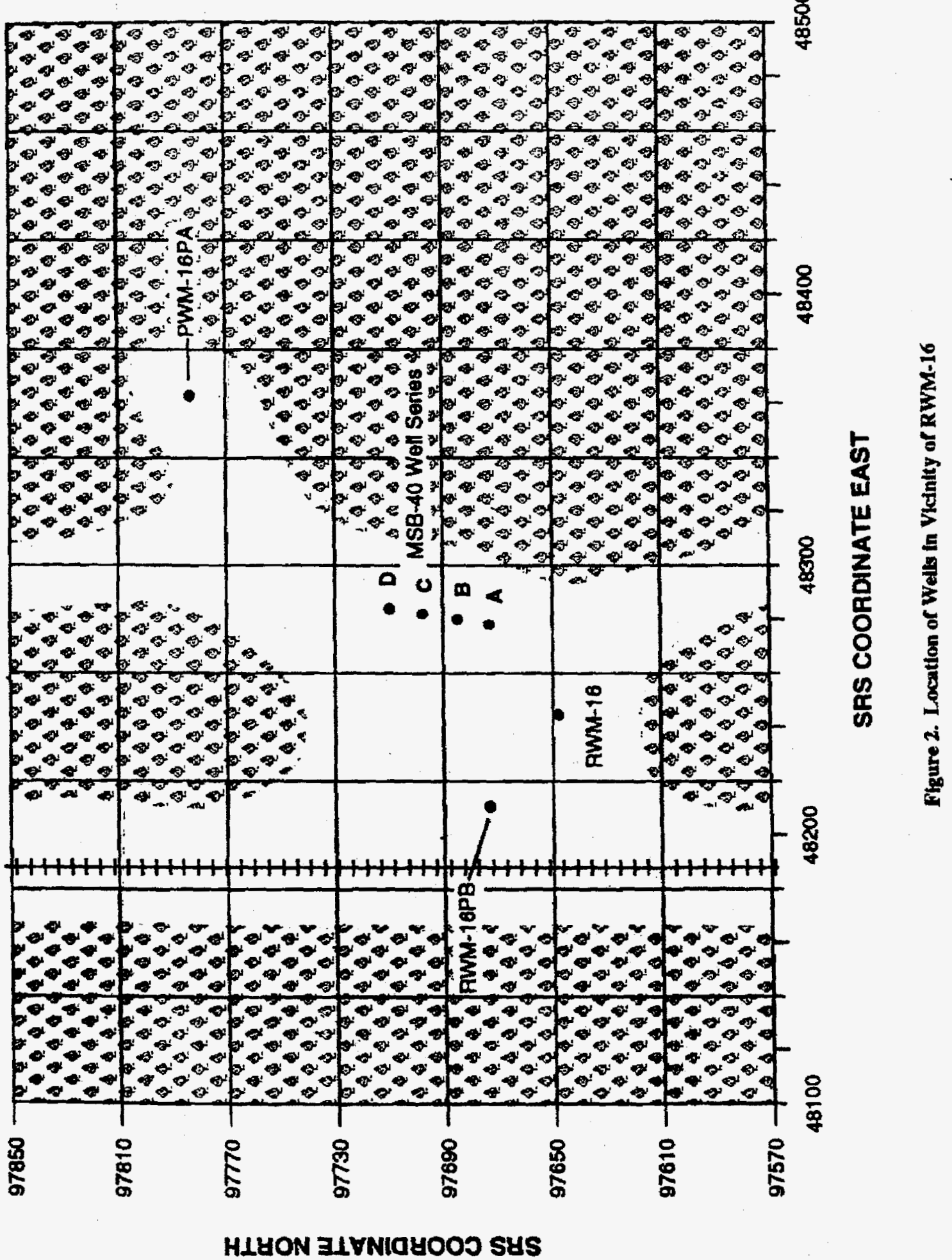




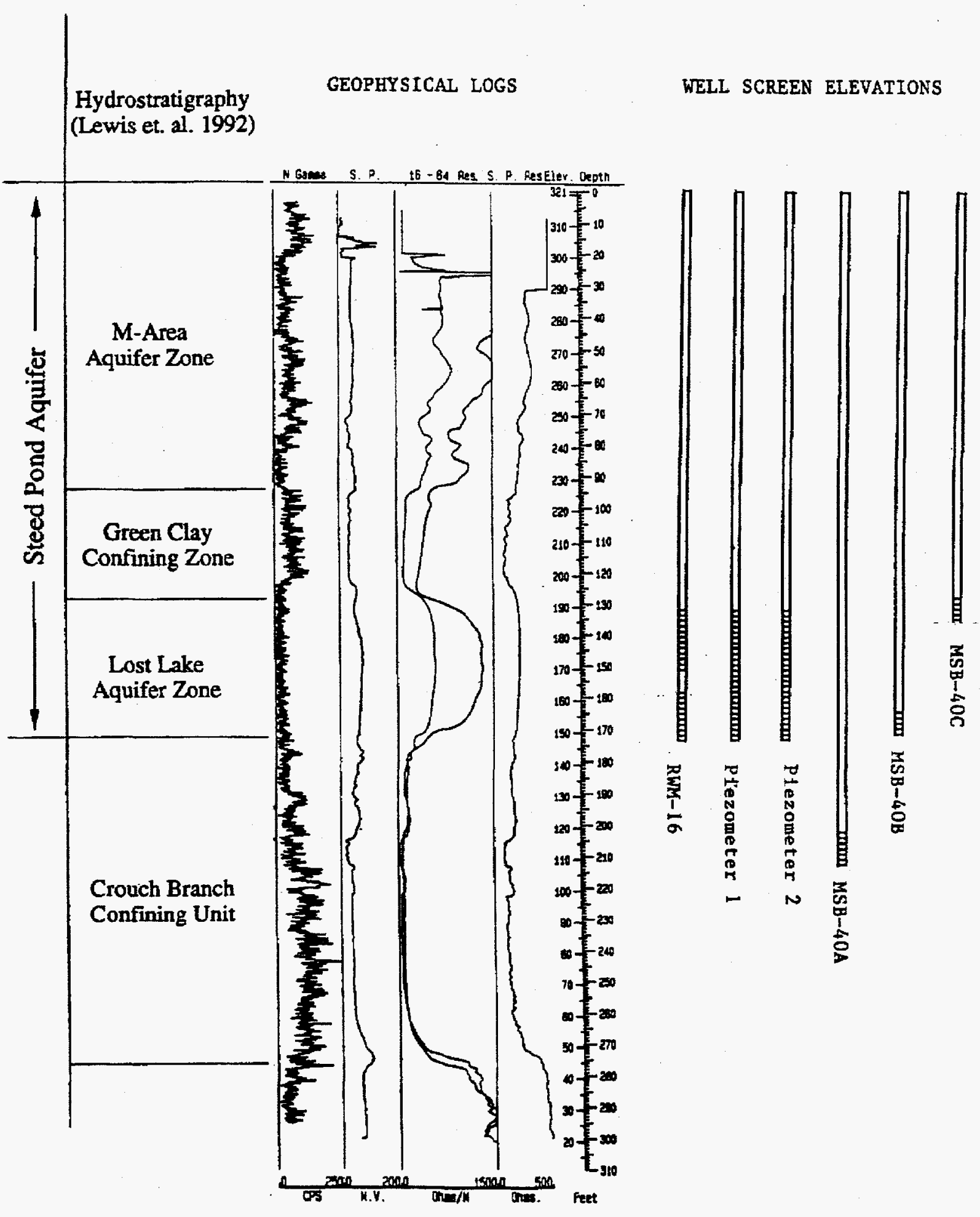

Figure 3. Stratigraphy, Geophysical Logs, and Well Screen Elevations 


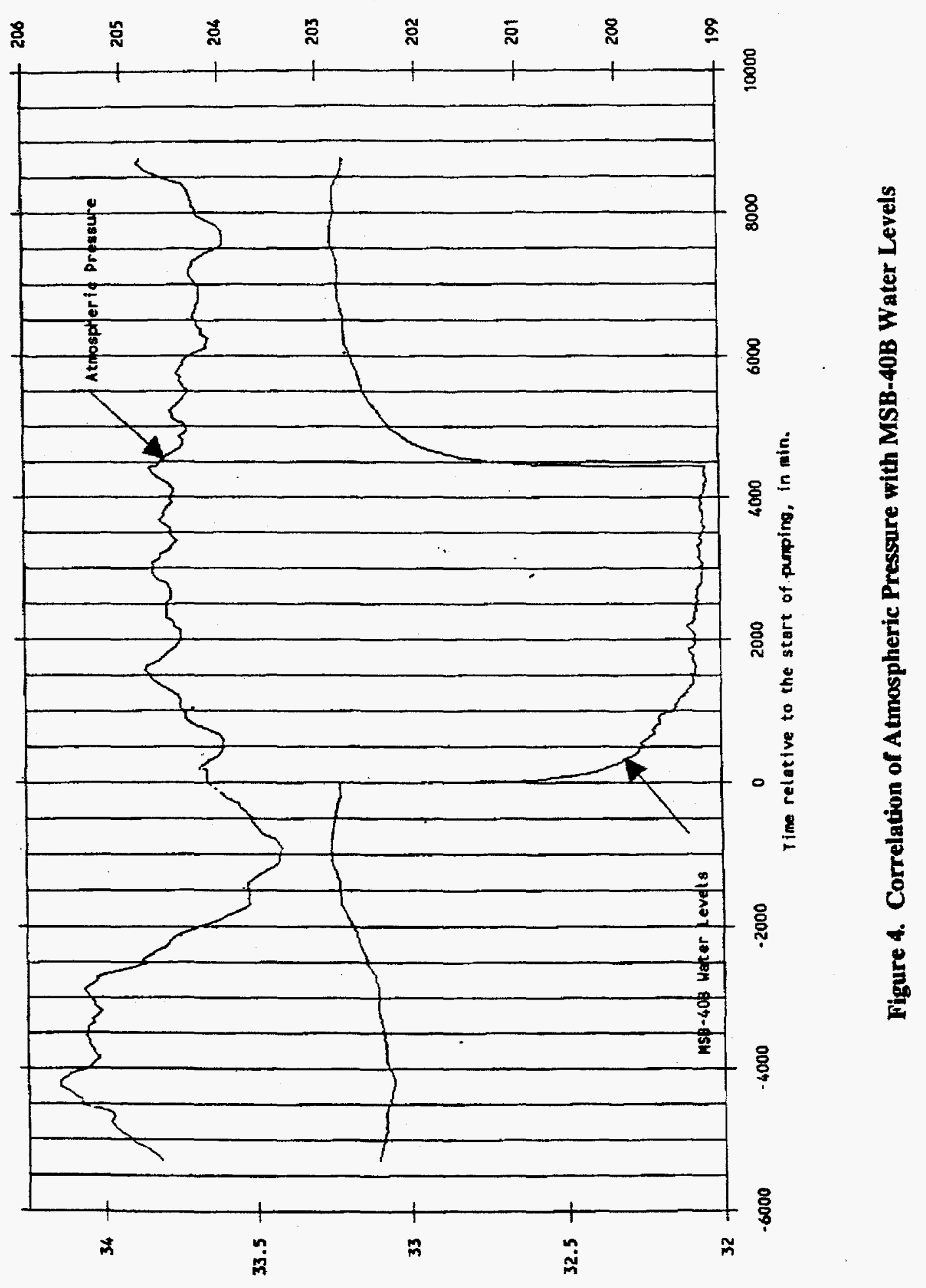




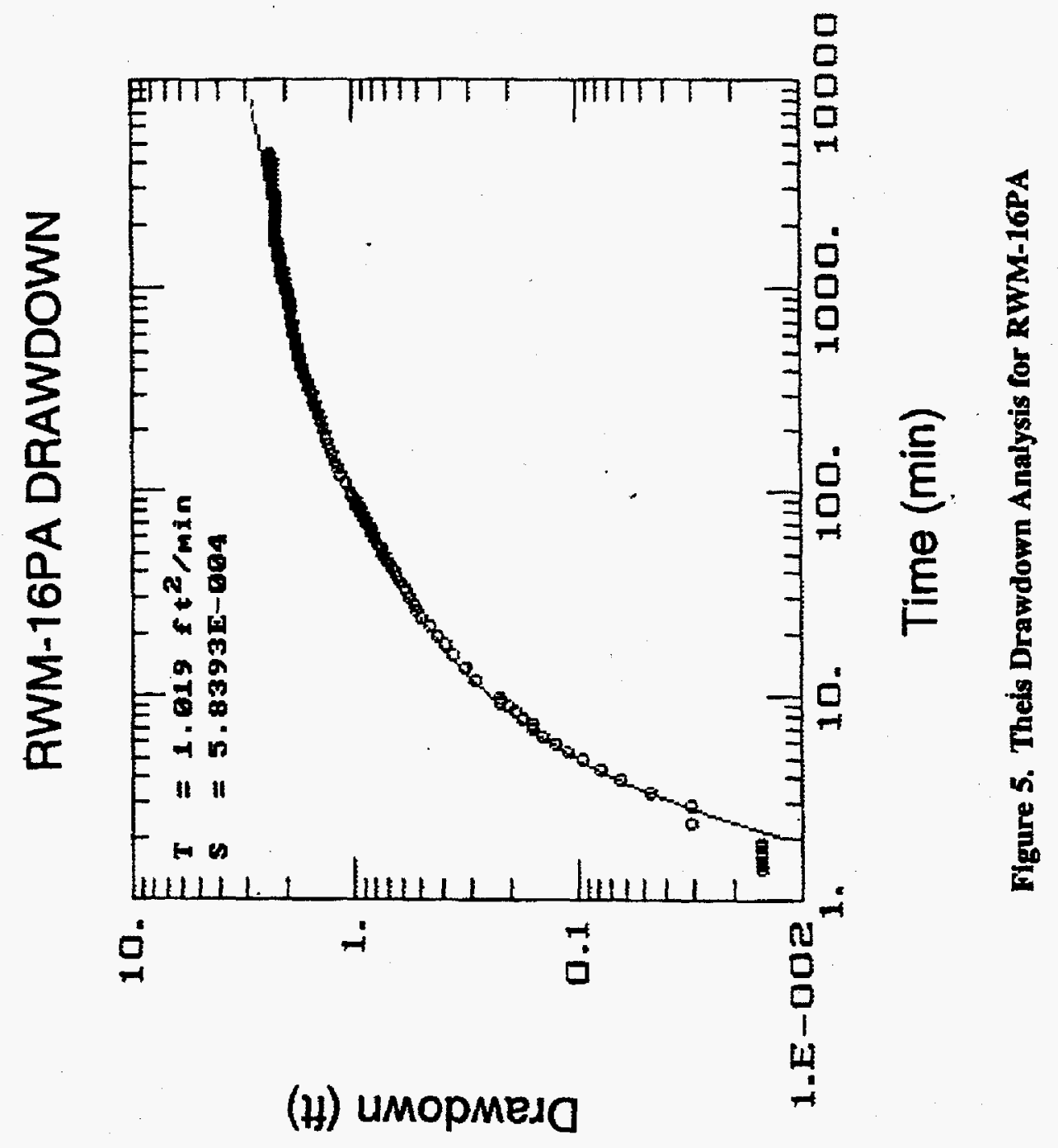




\section{RWM-16PA DRAWDOWN}

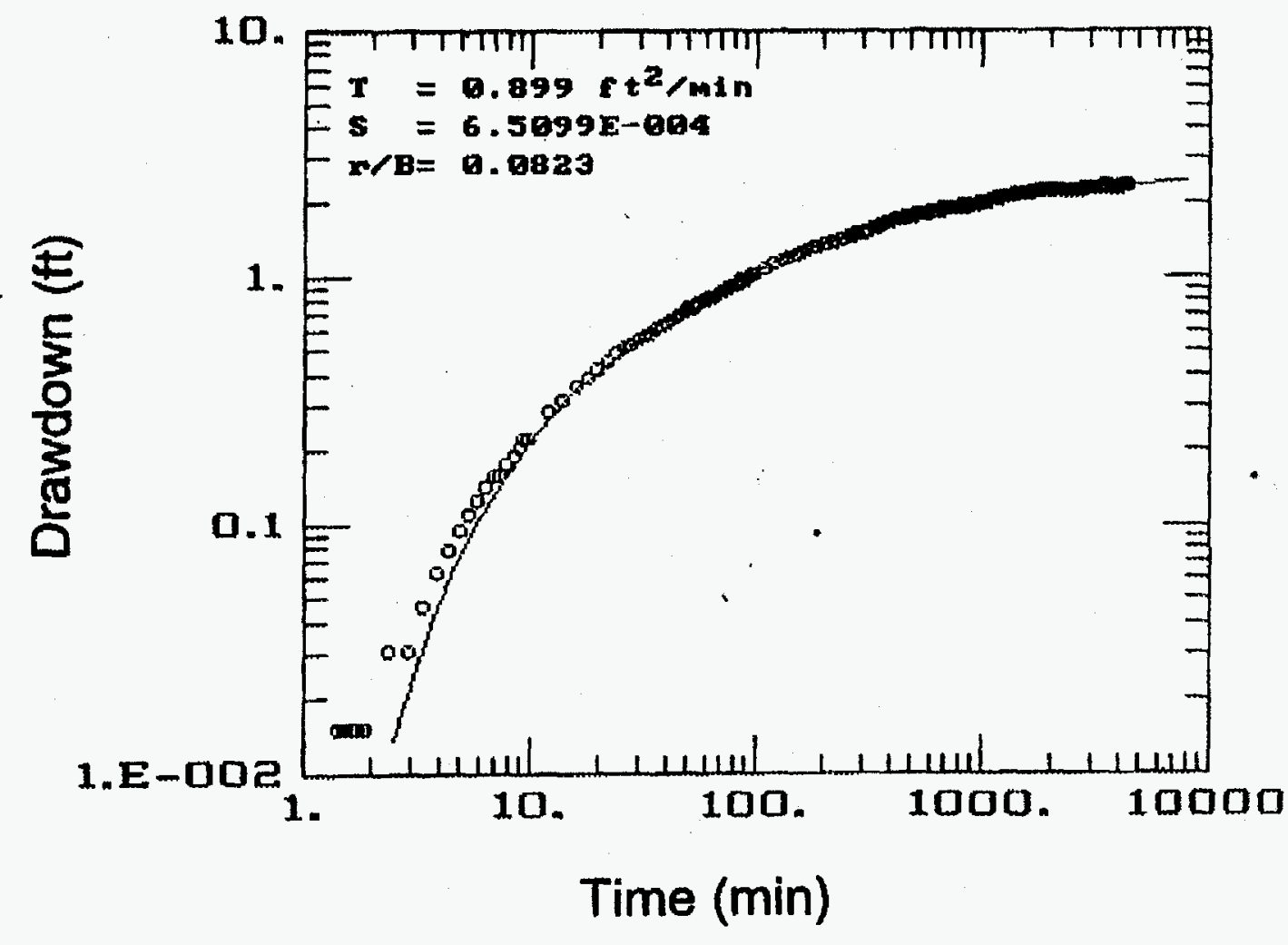

Figure 6. Hantush-Jacob (1955) Analysis for RWM-16PA 


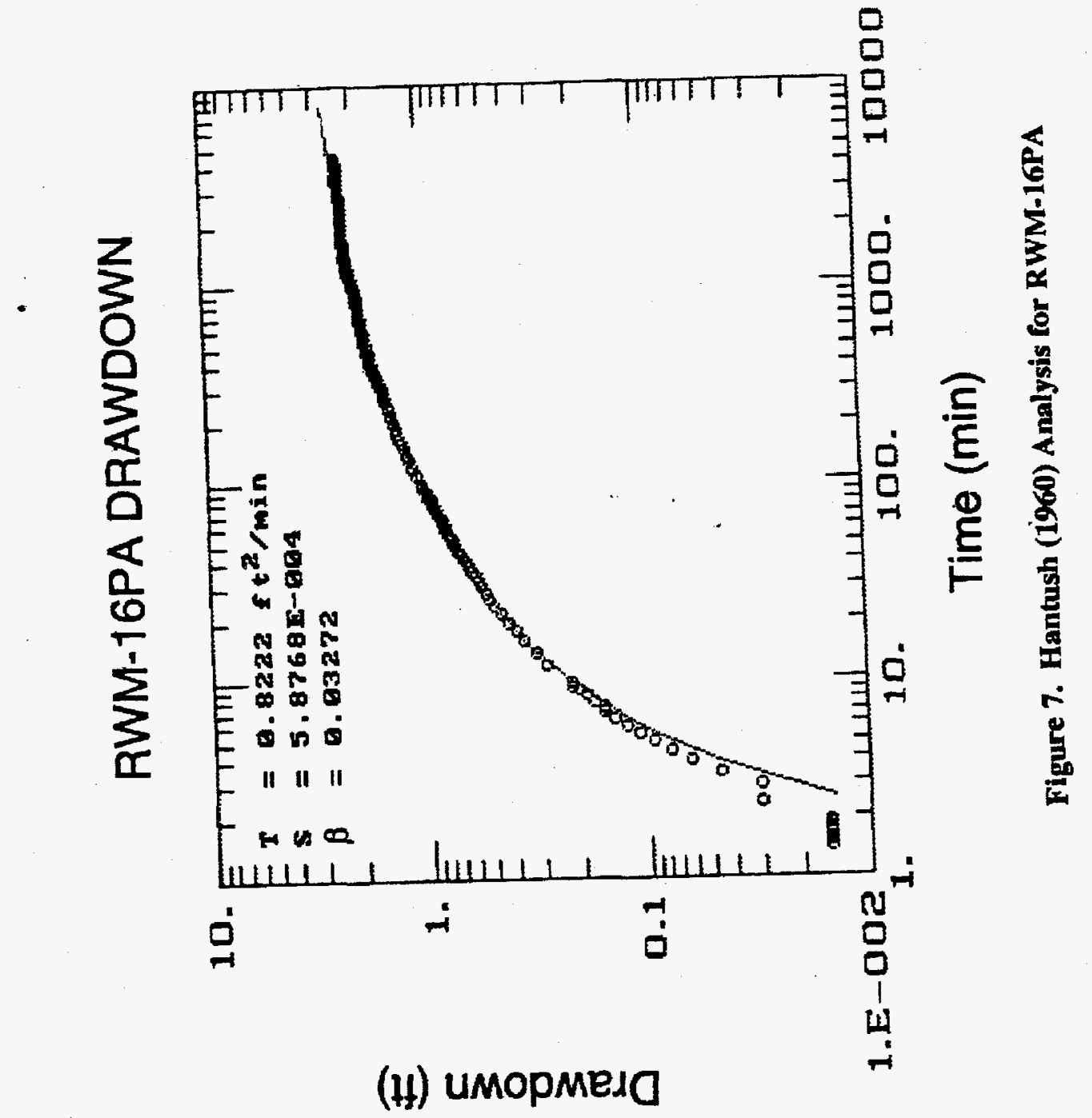




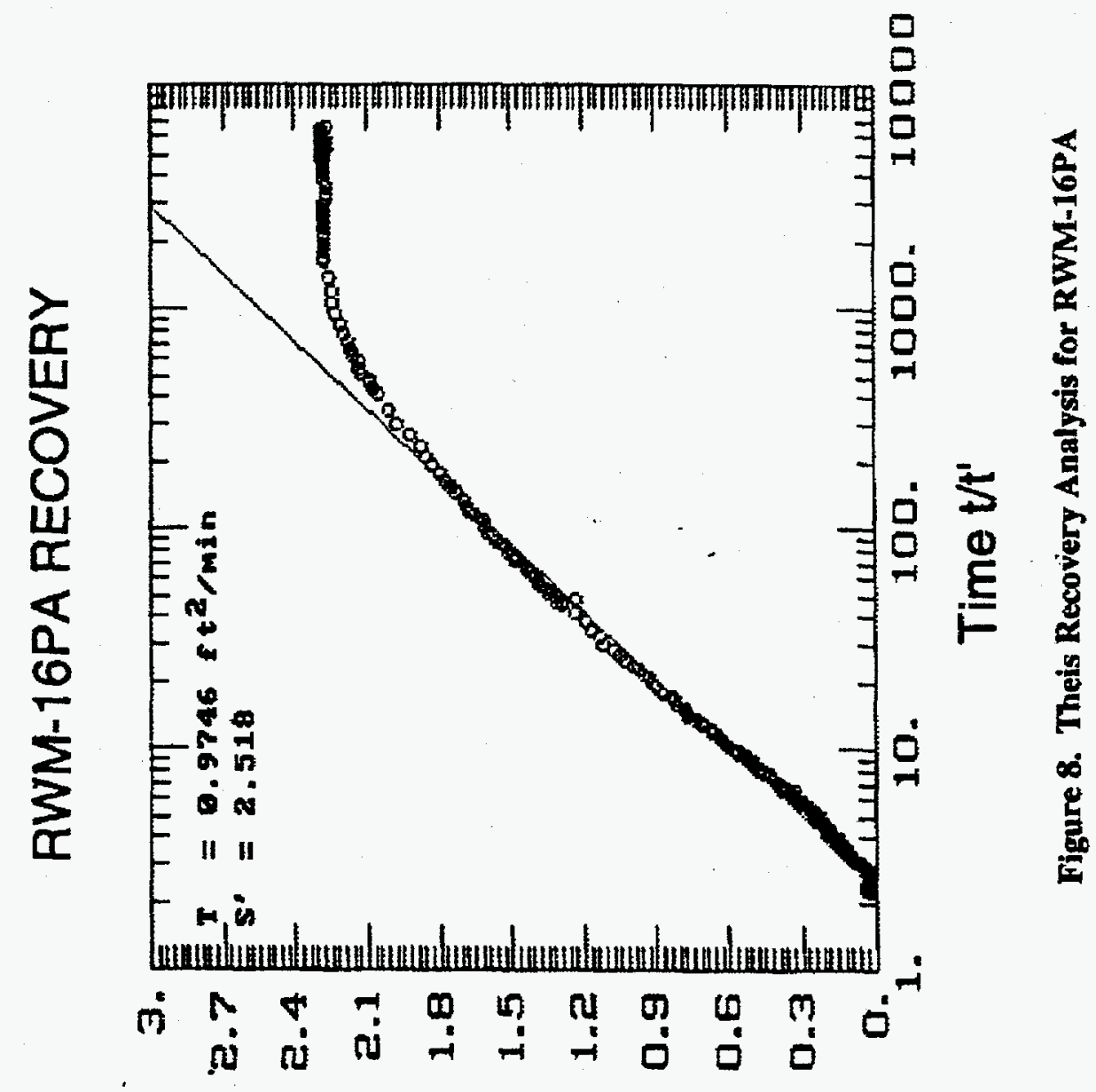

(H) имормеда jenpịsay 


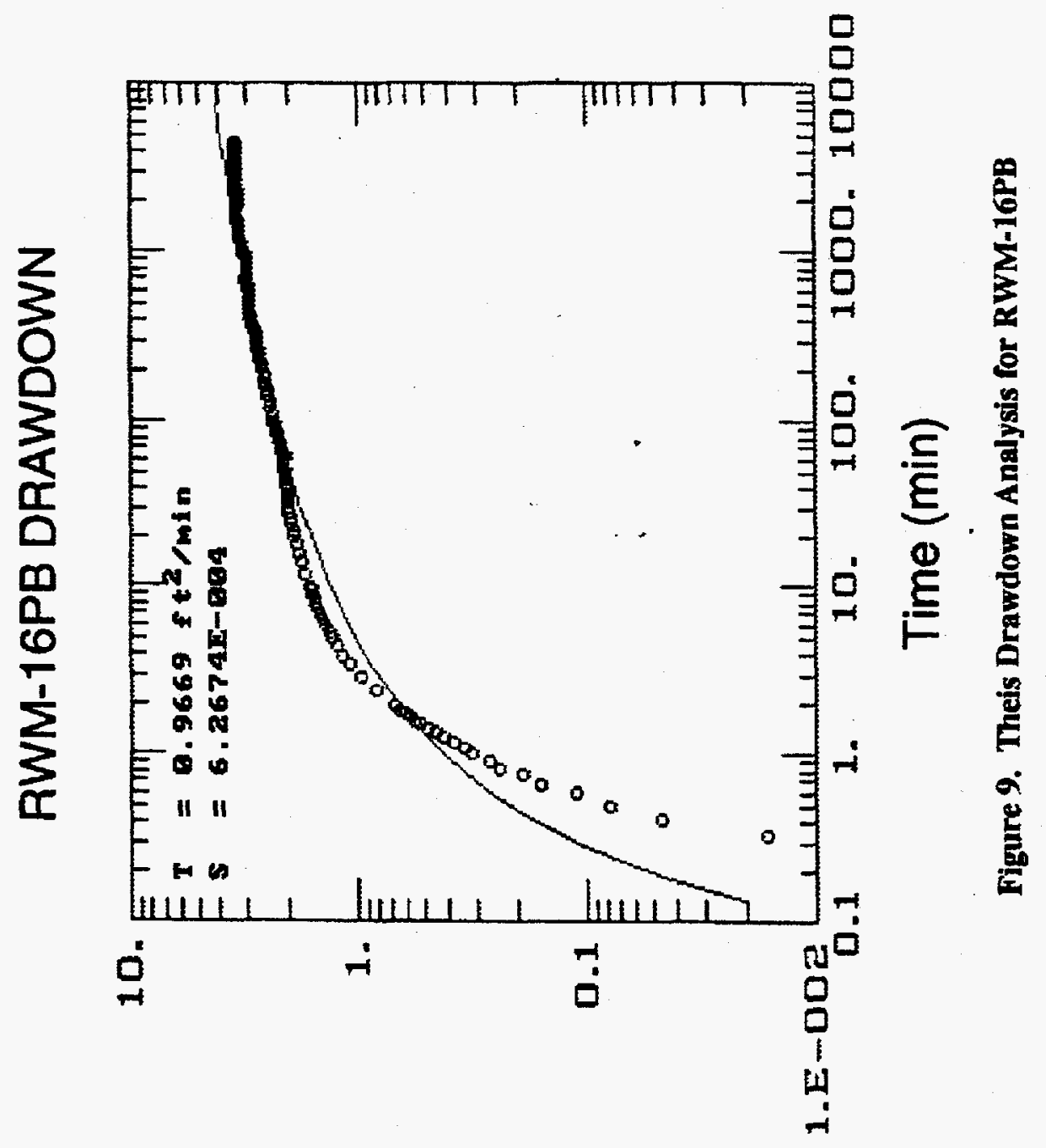

(н) имормејо 


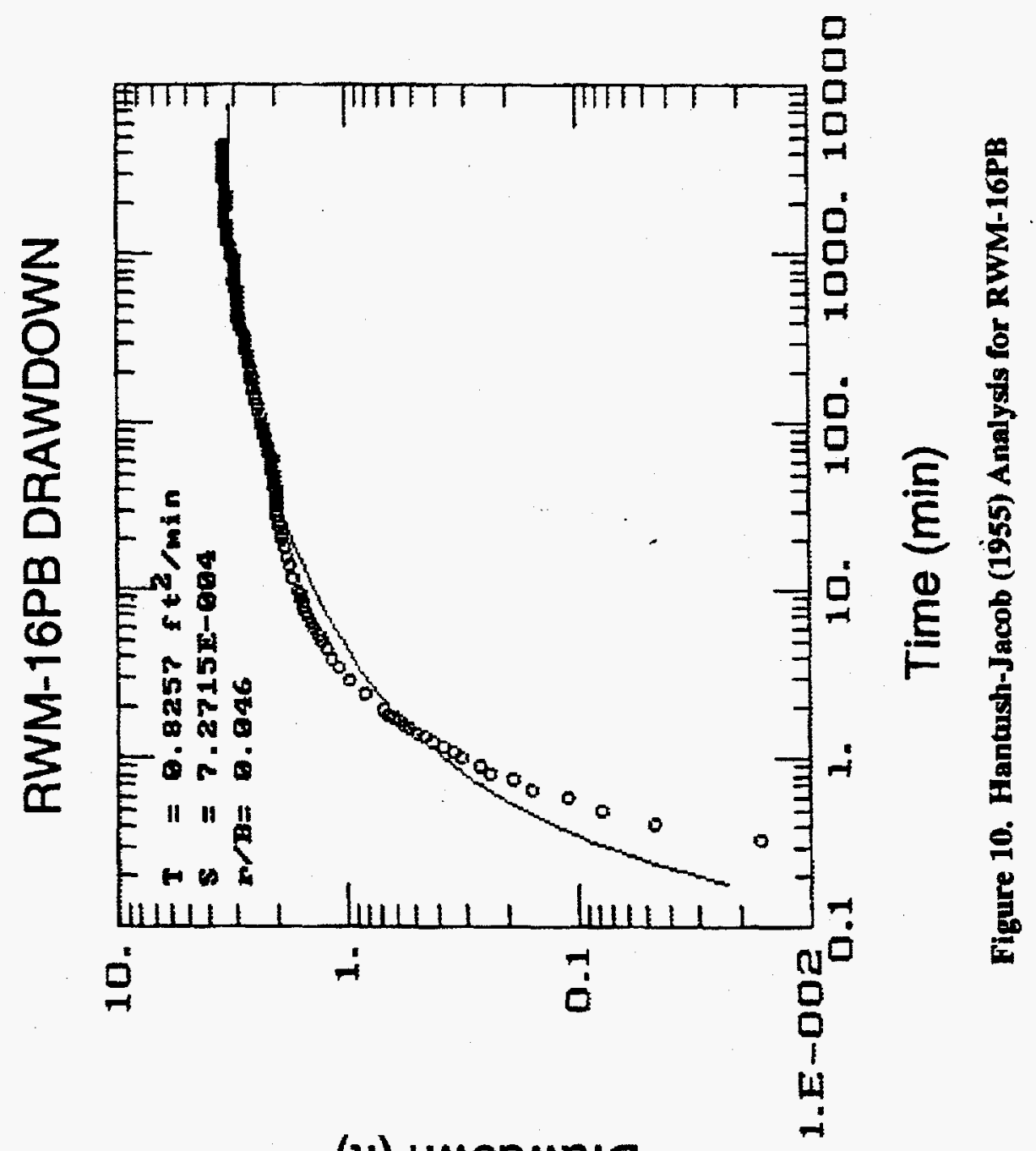

(н) имормело 


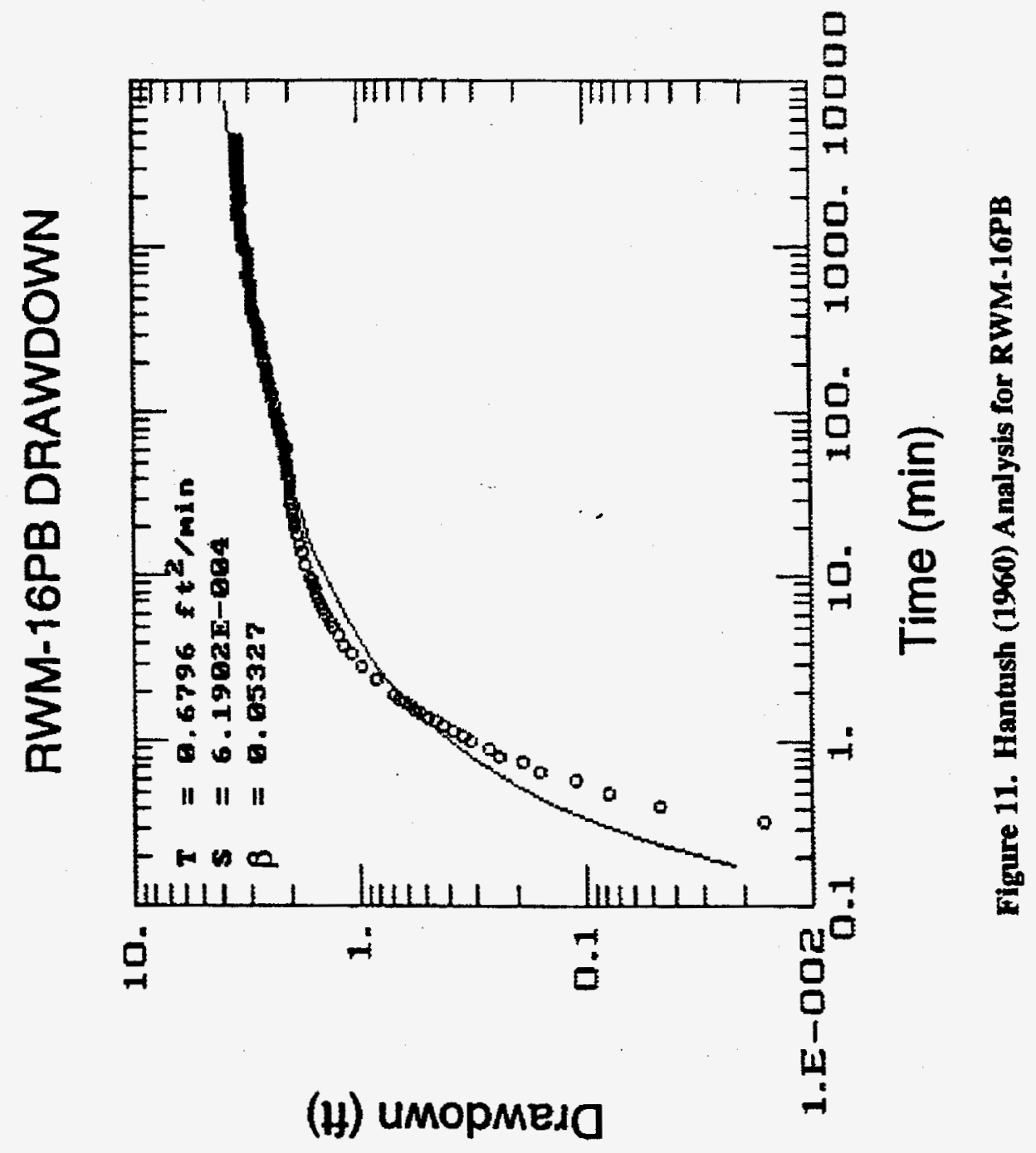




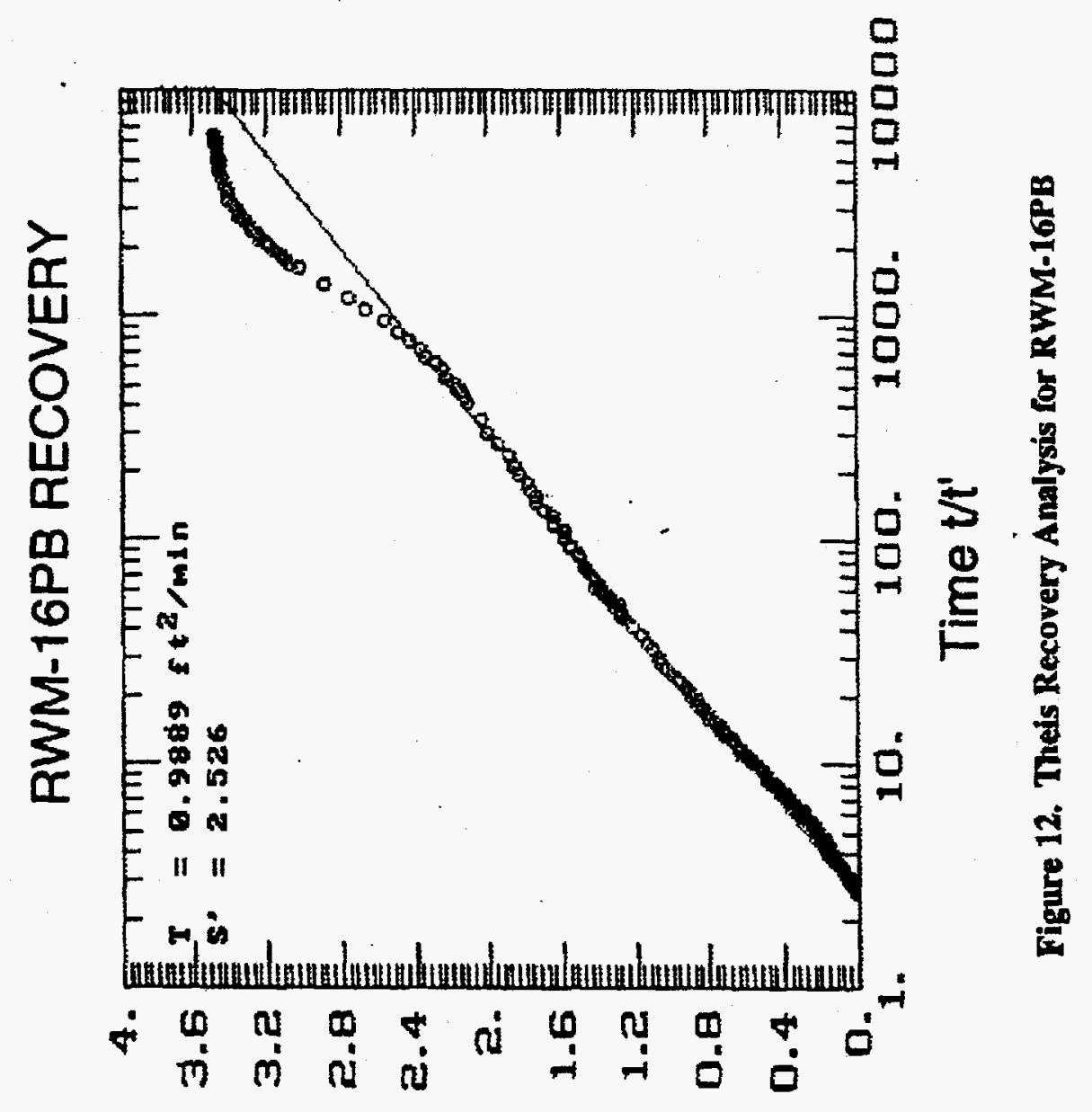

(H) имормеда jenp!sәy 


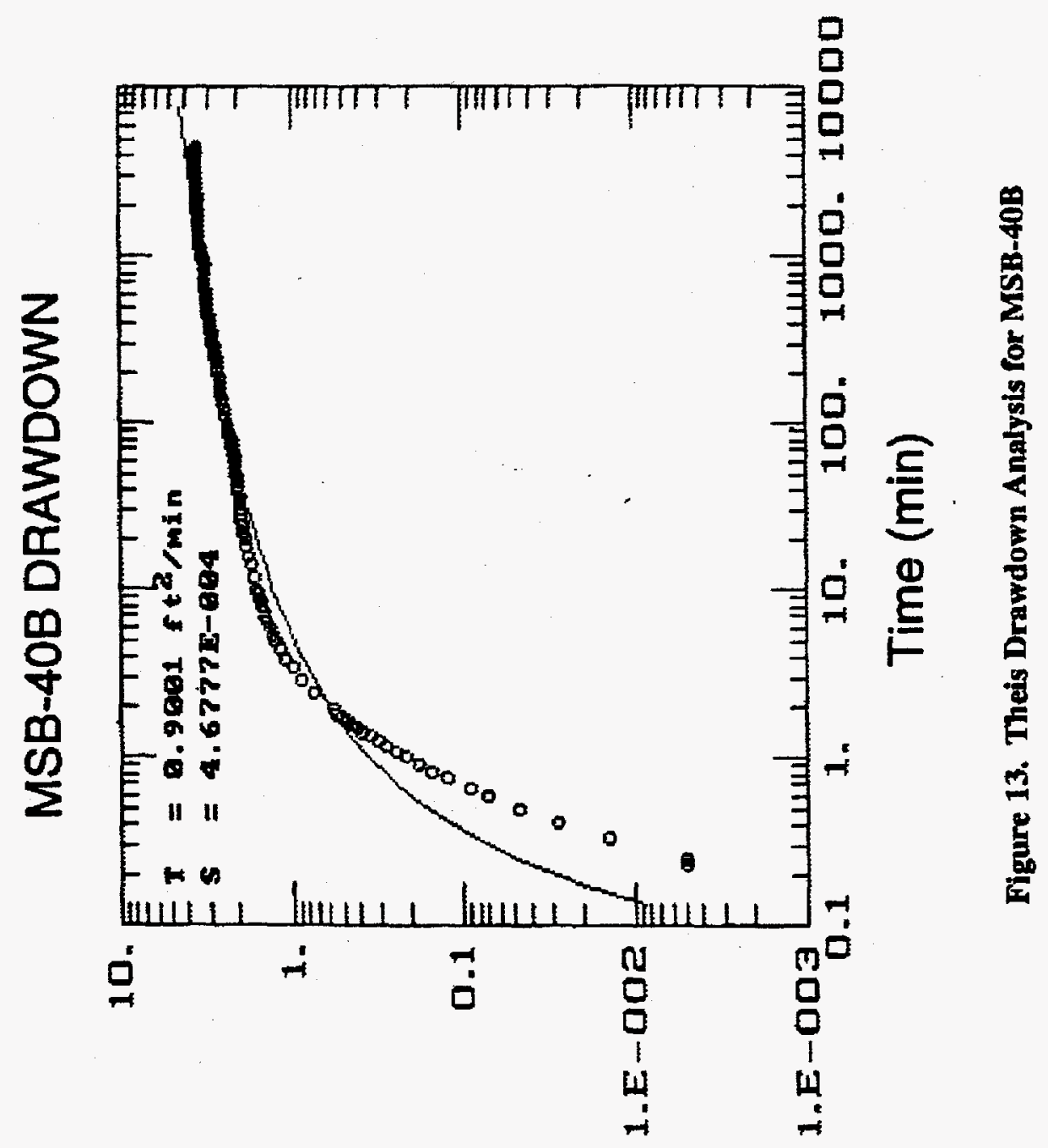

(H) имормела 


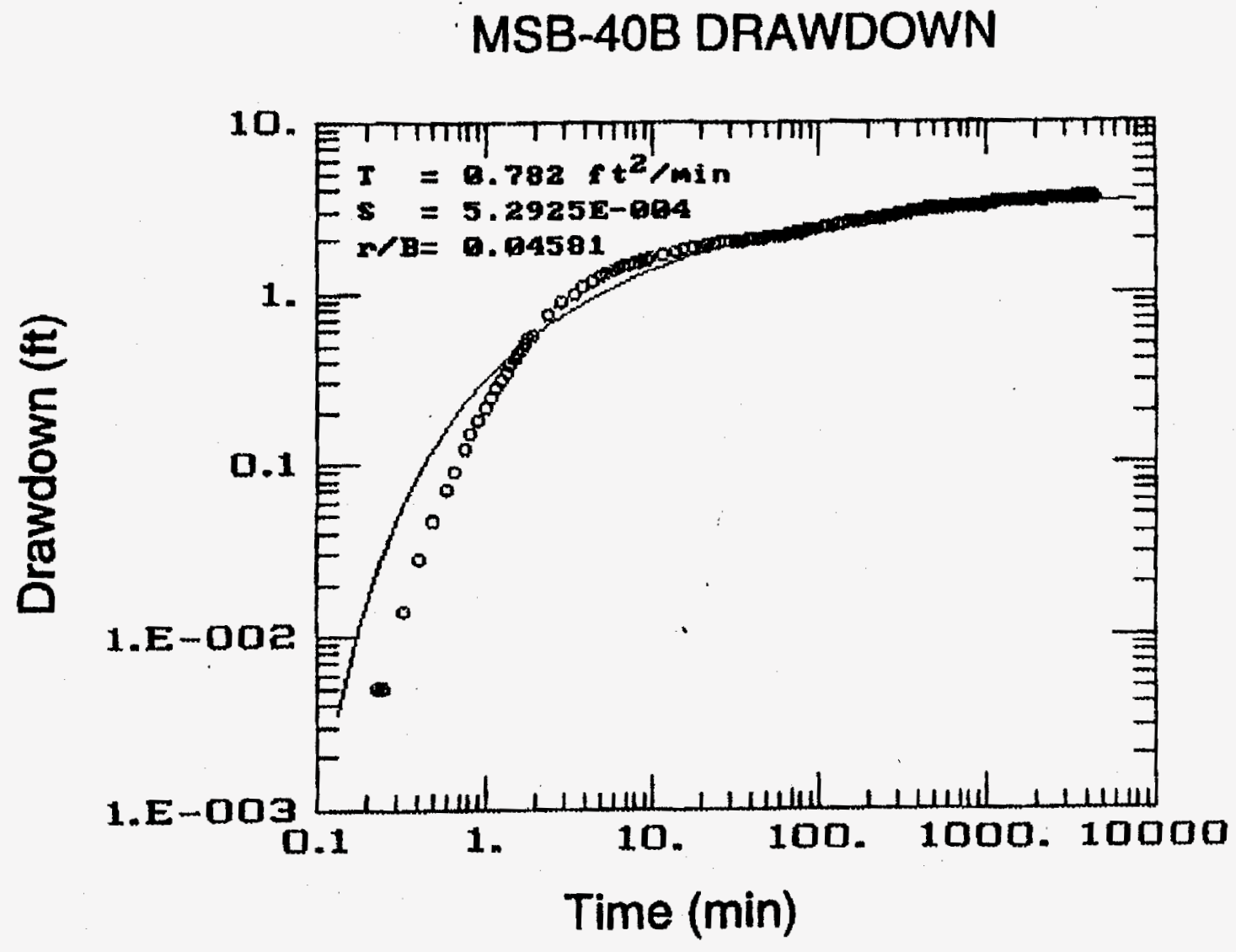

Figure 14. Hantush-Jacob (1955) Analysis for MSB-40B 


\section{MSB-40B DRAWDOWN}

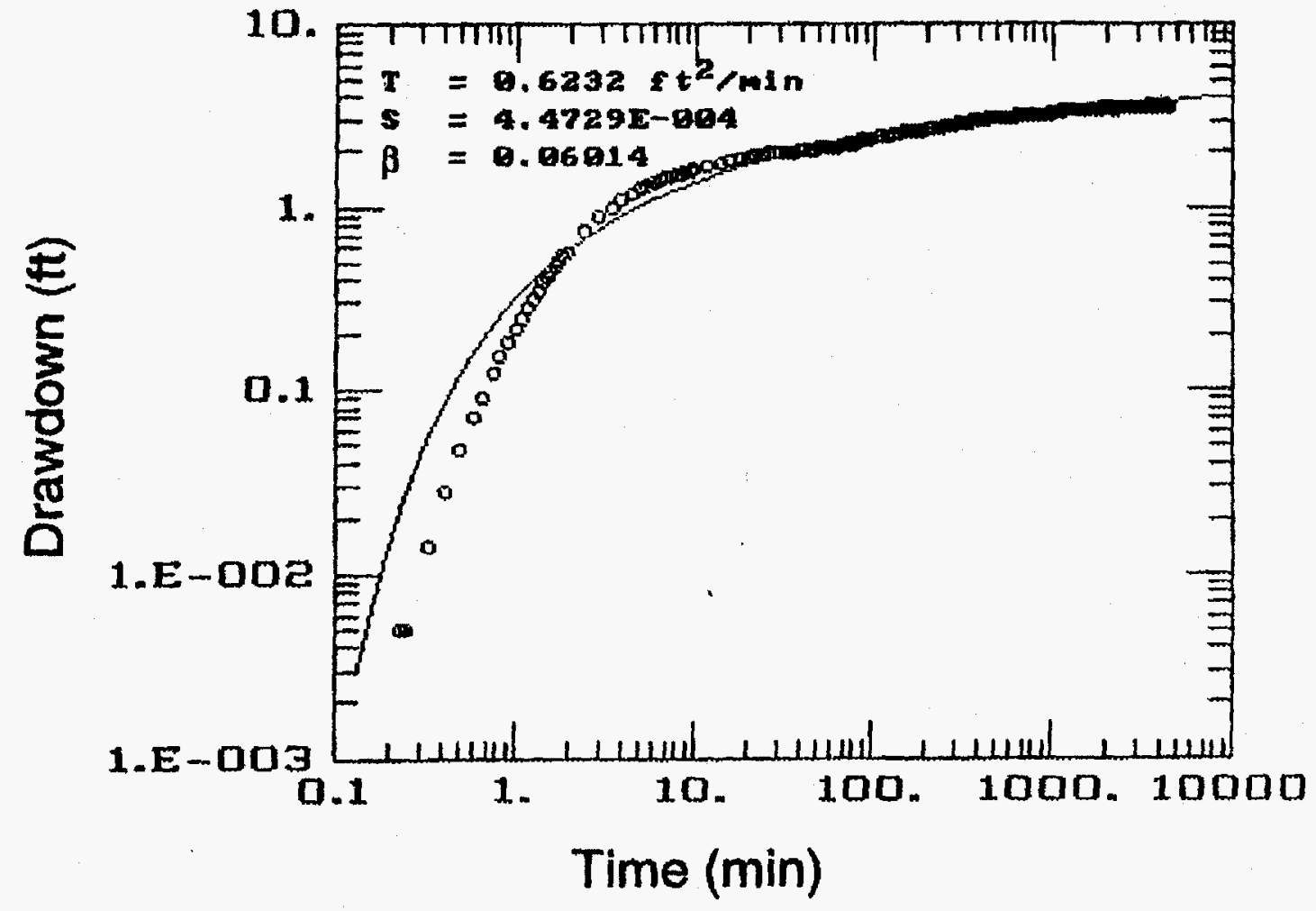

Figure 15. Hantush (1960) Analysis for MSB-40B 
MSB-40B RECOVERY

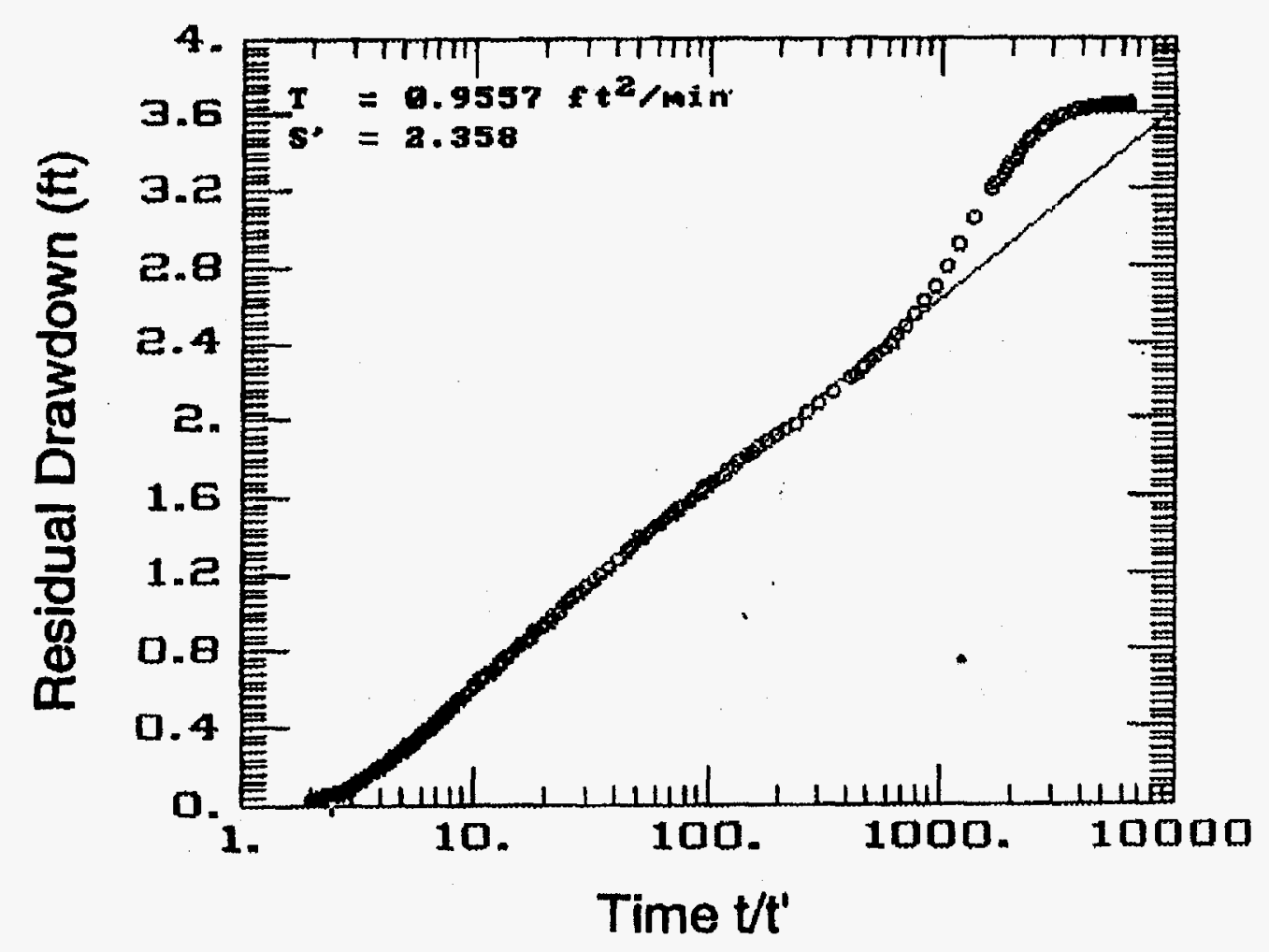

Figure 16. Theis Recovery Analysis for MSB-40B 


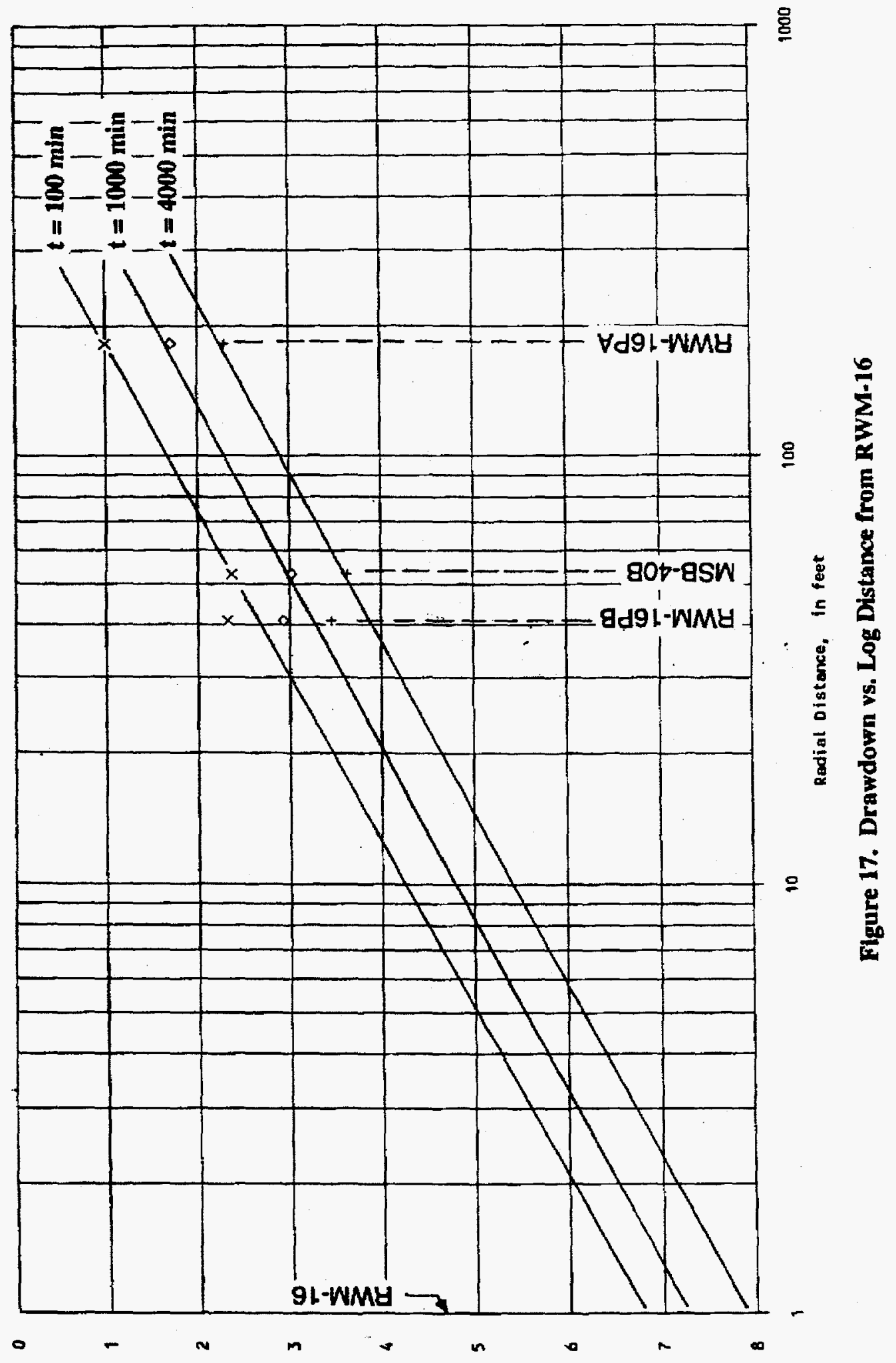



APPENDIX A 
BLANK 


\section{UNSTEADY FLOW TO A WELL IN A CONFINED AQUIFER}

REFERENCE: Theis, C.V., 1935. The relation between the lowering of the piezometric surface and the rate and duration of discharge of a well using groundwater storage, Am. Geophys. Union Trans., vol. 16, pp. 519-524.

ASSUMPTIONS: aquifer has infinite areal extent aquifer is homogeneous, isotropic, and of uniform thickness aquifer potentiometric surface is initially horizontal pumping rate is constant pumping well is fully penetrating flow to pumping well is horizontal aquifer is confined flow is unsteady water is released instantaneously from storage with decline of hydraulic bead

diameter of pumping well is very small so that storage in the well can be neglected

SOLUTION:

$s=Q /(4 \pi T) w(u)$

where:

$$
\begin{aligned}
& w(u)=\text { Theis well function }=\int_{u}^{\infty} \frac{e^{-y}}{y} d y \\
& u=r^{2} S /(4 T t)
\end{aligned}
$$




\section{UNSTEADY FLOW TO A WELL IN A CONFINED AQUTFER DURING RECOVERY}

REFERENCE: Theis, C.V., 1935 . The relation between the lowering of the piezometric surface and the rate and duration of discharge of a well using groundwater storage, Am. Geophys. Union Trans., vol. 16, pp. 519-524.

ASSUMPTIONS: aquifer has infinite areal extent

aquifer is homogeneous, isotropic, and of uniform thickness

aquifer potentionietric surface is initially horizontal

pumping rate is constant

pumping well is fully penetrating

flow to pumping well is horizontal

aquifer is confined

flow is unsteady

water is released instantaneously from storage with decline of hydraulic head

diameter of pumping well is very small so that storage in the well can be neglected

values of $u$ are small (i.e., $r$ is small and $t$ is large)

coefficient of storage is equal during pumping and recovery periods

SOLUTION:

$s^{\prime \prime}=Q /(4 \pi T)\left[\ln \frac{4 T t}{r^{2} S} \cdot \ln \frac{4 T t^{n}}{r^{2} S^{\prime \prime}}\right]$

where:

$s^{n}=$ residual drawdown $[L]$

$\mathbf{S}=$ coefficient of storage during pumping [dimensionless]

$S^{n}=$ coefficient of storage during recovery [dimensionless]

$t^{n}=\quad$ time since pumping stopped $[T]$ 


\section{UNSTEADY FLOW TO A WELL IN A SEMI-CONFINED AQUIFER WITH NO STORAGE IN AQUTTARDS}

REFERENCE: Hantush, M.S. and C.E. Jacob, 1955. Non-steady radial flow in an infinite leaky aquifer, Am. Geophys. Union Trans., vol. 36, pp. 95-100.

ASSUMPTIONS: aquifer has infinite areal extent

aquifer is homogeneous, isotropic, and of uniform thickness

aquifer potentiometric surface is initially horizontal

pumping rate is conistant

pumping well is fully penetrating

flow to pumping well is horizontal

aquifer is semi-confined

flow is unsteady

water is released instantaneously from storage with decline of hydraulic head

diameter of pumping well is very small so that storage in the well can be neglected

confining bed(s) has infinite areal extent, uniform vertical hydraulic conductivity, and uniform thickness

confining bed(s) is overlain or underlain by an infinite constant-head plane source

flow in the aquitard is vertical

SOLUTION:

$s=Q /(4 \pi T) w(u, r / B)$

where:

$$
\begin{aligned}
& w(u, r / B)=\text { well function of Hantush } \\
& =\int_{u}^{\infty}(1 / y) e^{-y-r^{2} /\left(4 B^{2} y\right)} d y \\
& u=r^{2} S /(4 T t)
\end{aligned}
$$


UNSTEADY FLOW TO A WELL IN A

SEMI-CONFINED AQUIFER WTH

NO STORAGE IN AQUTTARDS

(continued)

$\mathbf{B}=\left(\mathrm{Tb}^{\prime} / \mathrm{K}^{\prime}\right)^{\mathbf{h}}$
$\mathbf{b}^{\prime}=$ thickness of aquitard $[\mathrm{L}]$
$\mathbf{K}^{\prime}=$ vertical hydraulic conductivity of aquitard $[\mathrm{L} / \mathrm{T}]$ 


\section{UNSTEADY FLOW TO A WELL IN A SEMY-CONFINED AQUIFER WTH STORAGE IN AQUITARDS}

REFERENCE: Hantush, M.S., 1960. Modification of the theory of leaky aquifers, Jour. of Geophys. Res., vol. 65, no. 11, pp. 3713-3725.

ASSUMPTIONS: aquifer has infipite areal extent

aquifer is homogeneous, isotropic, and of uniform thickness

aquifer potentiometric surface is initially horizontal

pumping rate is constant

pumping well is fully penetrating

llow to pumping well is horizontal

aquifer is semi-confined

flow is unsteady

water is released instantaneously from storage with decline of hydraulic head

diameter of pumping well is very small so that storage in the well can be neglected

confining bed(s) has infinite areal extent, uniform vertical hydraulic conductivity and storage coefficient, and uniform thickness

confining bed(s) is overlain or underlain by an infinite constant-head plane source

flow in the aquitard is vertical

SOLUTION:

Hantush derived a solution for leaky aquifers with storage in the aquitards at small and large values of time. The solution included in AQTESOLV is for small values of time, i.e., $t<b^{\prime} S^{\prime} / 10 K^{\prime}$ and $t<b^{\prime \prime} S^{\prime \prime} / 10 K^{\prime \prime}$ :

$s=Q /(4 \pi T) H\left(u_{R} \beta\right)$

where:

$H\left(u_{2} \beta\right)=$ Hantush well function for leaky aquifers with storage in aquitards 


\section{UNSTEADY FLOW TO A WELL IN A \\ SEMI-CONIINED AQUIFER WTH \\ STORAGE IN AQUTTARDS \\ (continued)}

$$
\begin{aligned}
& =\int_{u}^{\infty} \frac{e^{-y}}{y} \operatorname{erfc} \frac{\beta u^{h}}{(y(y-u))^{h}} d y \\
& u=r^{2} S /(4 T t) \\
& \text { erfc }=\quad \text { complementary error function } \\
& \beta=\frac{r}{4}\left[\frac{\left(K^{\prime} S^{\prime}\right)^{k}}{\left(b^{\prime} T S\right)^{k}}+\frac{\left(K^{n} S^{n}\right)^{k}}{\left(b^{\prime \prime T S}\right)^{h}}\right] \\
& b^{\prime}=\quad \text { thickness of aquitard overlying aquifer [L] } \\
& K^{\prime}=\text { vertical hydraulic conductivity of aquitard overlying aquifer }[L / T] \\
& \mathbf{S}^{*}=\text { coefficient of storage of aquitard overlying aquifer [dimensionless] } \\
& \mathrm{b}^{\prime \prime}=\text { thickness of aquitard underlying aquifer [L] } \\
& \mathrm{K}^{\prime \prime}=\text { vertical bydraulic conductivity of aquitard underlying aquifer }[\mathrm{L} / \mathrm{T}] \\
& S^{n}=\quad \text { coefficient of storage of aquitard underlying aquifer [dimensionless] }
\end{aligned}
$$




\section{DISTRIBUTION}

\section{Copy \\ NO. DOESSR}

1. I. E. Bolen

2. L. C. Goidell

3. T. H. Hicks

4. T. C. Temples

$703-41 \mathrm{~A}$

703-A

$703-46 \mathrm{~A}$

WSRC

5. J.R. Cook

6. R. A. Hiergesell

7. R. H. Hsu

8. W. E. Stevens

9. A. D. Yu

10. R. K. Aadland

11. J. S. Haselow

12. B. B. Looney

13. R. L. Nichols

14. D. E. Stephens

15. J.W. Cook

16. R. Cumbest

17. J. D. Heffner

18. R. Hunter

19. J. L. Janssen

20. N. M. Park

21. V. Price

22. S. R. Reed

23. L.T. Reid

24. J. G. Sonnenberg

25. M. B. Amidon

26. C. L. Bergren

27. M. A. Ebra

28. T. F. Gaughan

29. M. K. Harris

30. J. Immell

31. S.E. Lewis

32. W. W. Pidcoe

33. W. R. Sims

34. J. Jordon

703-A

35 D. E. Wyatt

36. W. R. Sadler

37. L. Satomone

38. S. Serkiz

39. J. Ormand

773-43A

$773-43 A$

$773-43 \mathrm{~A}$

773-A

$773.43 \mathrm{~A}$

$773-42 A$

$773-42 A$

$773-42 A$

$773-42 \mathrm{~A}$

735-11A

742-A

$773-57 A$

735-16A

$772-7 \mathrm{~B}$

$772.7 \mathrm{~B}$

773-57A

773-57A

703-H

719-A

707-39B

992-4W

$992-4 W$

992-4W

992-4W

$992-4 W$

$992-4 W$

992-4W

992-4W

$9924 W$

$992-4 W$

$992-4 W$

$992-4 W$

966-W

992-4W

$777-10 \mathrm{~A}$

40. C. W. Tope

$703-43 \mathrm{~A}$

41-45. Document and Records Administration 773-52A 